\title{
[1,1-( $\eta^{2}$-dppe)-3-( $\left.\left.\mathrm{NC}_{5} \mathrm{H}_{5}\right)-c / o s o-1,2-\mathrm{RhSB}_{9} \mathrm{H}_{8}\right]$ : conformational lability and reactivity with $\mathrm{H}_{2}$ upon protonation†
}

Ana C. Mateo, ${ }^{a}$ Beatriz Calvo, ${ }^{a, b}$ Ramón Macías, ${ }^{\star a}$ María José

Artigas, ${ }^{a}$ Fernando J. Lahoz ${ }^{a}$ and Luis A. Oro*a,b

a Instituto de Síntesis Química y Catálisis Homogénea (ISQCH), Universidad de ZaragozaConsejo Superior de Investigaciones Científicas, 50009-Zaragoza, Spain.

E-mail: oro@unizar.es, rmacias@unizar.es; Tel: +34 976761143

${ }^{b}$ Center of Research Excellence in Petroleum Refining and Petrochemicals, King Fahd University of Petroleum and Minerals (KFUPM), Dhahran 31261, Saudi Arabia †Dedicated to the memory of Professor Ken Wade, a pattern-maker in cluster chemistry.

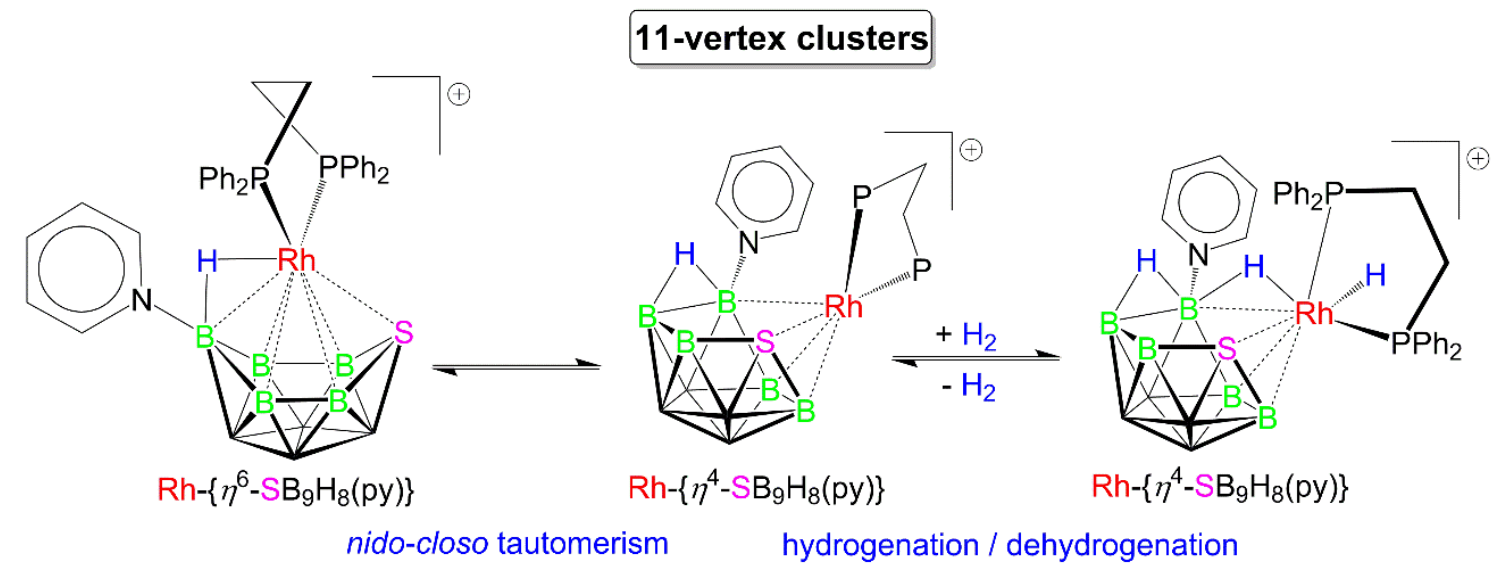

The $\left\{\mathrm{SB}_{9} \mathrm{H}_{8}\left(\mathrm{NC}_{5} \mathrm{H}_{5}\right)\right\}$-to- $\{\mathrm{Rh}(\mathrm{dppe})\}$ linkage is labilized upon protonation leading to a closo $\leftrightarrow$ nido tautomerism; non-rigidity and higher Lewis acidity, induced by the proton, make possible the $\mathrm{H}_{2}$ activation on the cationic rhodathiaborane. 


\section{Abstract}

Metallaheteroboranes are versatile compounds that can be conveniently modified and eventually tailored by ligand modification at either the metal centre or the boron vertices. Recently, we have discovered that protonation of some rhodathiaboranes affords cationic clusters with interesting reaction chemistry. In order to tune the reactivity of some of these polyhedral boron-based compounds, we have prepared air-stable orange [1,1-( $\eta^{2}$-dppe)-3- $\left(\mathrm{NC}_{5} \mathrm{H}_{5}\right)$-closo-1,2- $\left.\mathrm{RhSB}_{9} \mathrm{H}_{8}\right]$ (2) by the treatment of the known hydridorhodathiaborane $\left[8,8,8-(\mathrm{H})\left(\mathrm{PPh}_{3}\right)_{2}-9-\left(\mathrm{NC}_{5} \mathrm{H}_{5}\right)\right.$-nido-8,7- $\left.\mathrm{RhSB}_{9} \mathrm{H}_{9}\right]$ (1) with dppe. The new 11-vertex rhodathiaborane, 2, reacts readily with triflic acid $(\mathrm{TfOH})$ in $\mathrm{CH}_{2} \mathrm{Cl}_{2}$ to give orange cationic [8,8-( $\left.\eta^{2}-\mathrm{dppe}\right)-9-\left(\mathrm{NC}_{5} \mathrm{H}_{5}\right)-$ nido-8,7$\left.\mathrm{RhSB}_{9} \mathrm{H}_{9}\right]^{+}$(3). VT NMR experiments have allowed the characterization of a structural closo $\leftrightarrow$ nido tautomerism, which involves hapticity changes in the ligation of the $\left\{\mathrm{SB}_{9} \mathrm{H}_{9}-\left(\mathrm{NC}_{5} \mathrm{H}_{5}\right)\right\}$ moiety to the $\{\mathrm{Rh}(\mathrm{dppe})\}$ fragment, with the proton moving between the $\mathrm{Rh}(1)-\mathrm{B}(3)$ and the $\mathrm{B}(9)-\mathrm{B}(10)$ edges of the closo- and nidoisomers, respectively. The proton enhances the stereochemical non-rigidity and Lewis acidity of 3 versus the neutral 2 . This modification of the chemical and structural basis permits the efficient heterolytic splitting of the $\mathrm{H}-\mathrm{H}$ bond, leading to the formation of new hydridorhodathia-borane isomers $\left[8,8,8-(H)\left(\eta^{2}-d p p e\right)-\mu-\right.$ 8,9-(H)-9- $\left(\mathrm{NC}_{5} \mathrm{H}_{5}\right)$-nido-8,7- $\left.\mathrm{RhSB}_{9} \mathrm{H}_{10}\right]^{+}$(4) that are in equilibrium with the reactants, $\mathrm{H}_{2}$ and 3 .

\section{Introduction}

The possibility to tune the reactivity of homogeneous catalysts by the modification of their chemical and structural basis by, for example, the use of different ligands is without doubt one of the reasons behind the interest in the organometallic chemistry of transition element complexes. ${ }^{1}$

Just as metal complexes, the reactivity of metallaboranes and metallaheteroboranes can be adjusted by the systematic modification of the chemical composition of the metal-bound ligands as well as the heteroborane fragments. ${ }^{2}$ There is thus great potential for the use of polyhedral boron-based clusters that incorporate different metal fragments in their structures 
(i.e., metallaboranes and metallaheteroboranes) in areas such as catalysis.

In recent years, we have demonstrated this potential in that the reactivity of new 11-vertex rhodathiaboranes has been systematically tailored by changing the exo-polyhedral ligands at the rhodium centre, at a boron vertex or both. ${ }^{3-6}$ It has, thus, been possible to activate dihydrogen on the new 11-vertex closo-rhodathiaboranes, and to prepare hydridorhodathiaboranes capable of undergoing oxidative addition of sp $\mathrm{C}-\mathrm{H}$ bonds, and catalytic hydrogenation and isomerization of olefins..$^{7-9}$

Most recently, we have discovered that protonation of some of these 11-vertex rhodathiaboranes with strong Brønsted acids is a simple way of influencing the structural and electronic properties of these polyhedral clusters. By simple protonation, it is possible to labilize the metal-thiaborane linkage leading to an increase of the structural non-rigidity of the deltahedral clusters and of their Lewis acidity, promoting consequently new reactivity that allows the optimization of $\mathrm{H} 2$ splitting on cationic 11-vertex rhodathiaboranes. ${ }^{10,11-14}$

In this manuscript, the possibility of influencing the reactivity of metallaheteroboranes by modifying the exo-polyhedral ligands and by the protonation of the clusters is further demonstrated with the synthesis of new 11-vertex rhodathiaboranes that contain the bis (diphenylphosphino)ethane (dppe) ligand. In comparison with monodentate phosphines previously studied, ${ }^{11,13,14}$ the use of a chelating ligand such as dppe has shown to have a large influence on the structural and electronic properties of the 11-vertex cluster, which allows the characterization of a new tautomeric process that reflects the non-rigidity of the dppe-ligated cationic species and (ii) the reversible addition of $\mathrm{H}_{2}$ to the cage.

\section{Results and discussion}

\section{Synthesis and characterization}

The reaction of $\left[8,8,8-(\mathrm{H})\left(\mathrm{PPh}_{3}\right)_{2}-9-\left(\mathrm{NC}_{5} \mathrm{H}_{5}\right)-\right.$ nido-8,7- $\left.\mathrm{RhSB}_{9} \mathrm{H}_{9}\right]$ with dppe at the reflux temperature in dichloromethaneaffords the new dppe-ligated 11-vertex rhodathiaborane, [1,1( $\eta^{2}$-dppe)-3- $\left(\mathrm{NC}_{5} \mathrm{H}_{5}\right)$-closo-1,2- $\mathrm{RhSB}_{9} \mathrm{H}_{8}$ ] (2) with a $65 \%$ yield (Scheme 1).

The reaction involves the substitution of the two $\mathrm{PPh}_{3}$ ligands by the chelating dppe ligand and the formal loss of $\mathrm{H}_{2}$ from the cluster. From the cluster view point, the loss of two hydrogen atoms leads to the reduction of two skeletal electrons in the bonding of the cage, therefore, the observed nido-to-closo structural transformation of the 11-vertex cluster is in accord with the electron counting rules derived by Wade..$^{15}$ In other words, the reaction of 1 with dppe to give 2 is a ligand substitution and cluster oxidation process (Scheme 1). 

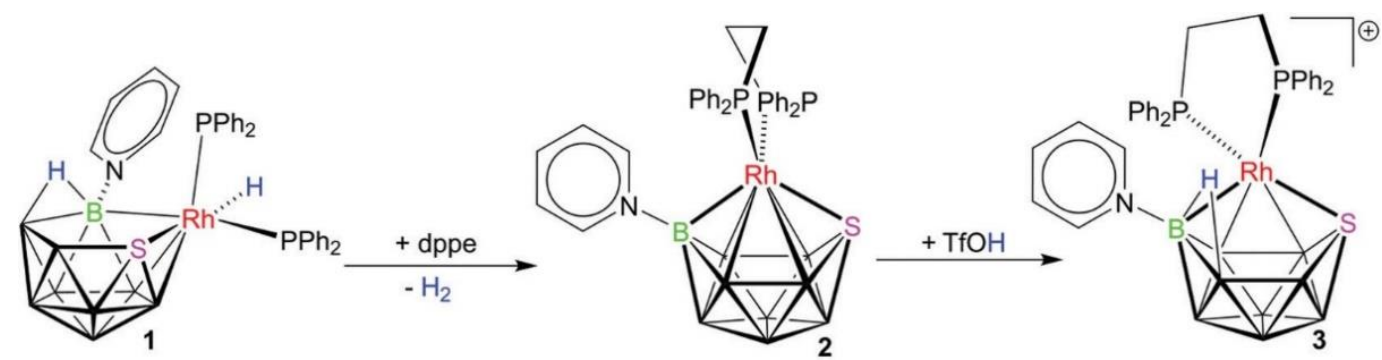

Scheme 1 Reaction of $\mathbf{1}$ with dppe to give $\mathbf{2}$, and its protonation with triflic acid to form $\mathbf{3}$.

The treatment of 2 with triflic acid $(\mathrm{TfOH})$ leads to the protonation of the closo-cage to give the polyhedral cation, $\left[8,8-\left(\eta^{2}-d p p e\right)-9-\left(\mathrm{NC}_{5} \mathrm{H}_{5}\right)-\text { nido-8,7-RhSB}{ }_{9} \mathrm{H}_{9}\right]^{+}$(3) (Scheme 1).

Compounds 2 and $\mathbf{3}$ have been characterized by multinuclear NMR spectroscopy, mass spectrometry and X-ray diffraction, and their structures and spectroscopic data are discussed below.

Table 1 lists some selected distances and angles of $\mathbf{2}$ and $\mathbf{3}$. The molecular structure of $\mathbf{2}$ is based on an octadecahedron, which is a deltahedron that is predicted by the simple application of the Wade rules for an 11-vertex closo-cluster with twelve skeletal electron pairs. Alternatively, 2 can be described as a coordination compound that features a hexahapto ligation of the $\left\{\mathrm{SB} 9 \mathrm{H}_{8}\left(\mathrm{NC}_{5} \mathrm{H}_{5}\right)\right\}$ moiety to the rhodium atom.

Table 1 Selected interatomic distances $(\AA)$ and angles $\left(^{\circ}\right)$ for $\left[1,1-\left(\eta^{2}-\right.\right.$ dppe $)-3-\left(\mathrm{NC}_{5} \mathrm{H}_{5}\right)-$ closo-1,2$\left.\mathrm{RhSB}_{9} \mathrm{H}_{8}\right](2)$ and $\left[8,8-\left(\eta^{2}-\mathrm{dppe}\right)-9-\left(\mathrm{NC}_{5} \mathrm{H}_{5}\right)-\text {-nido-8,7-RhSB}{ }_{9} \mathrm{H}_{9}\right]^{+}(\mathbf{3})$

\begin{tabular}{llll}
\hline $\mathbf{2}$ & \multicolumn{3}{c}{$\mathbf{3}$} \\
\hline $\mathrm{Rh}(1)-\mathrm{P}(1)$ & $2.2482(5)$ & $\mathrm{Rh}(8)-\mathrm{P}(1)$ & $2.274(3)$ \\
$\mathrm{Rh}(1)-\mathrm{P}(2)$ & $2.2748(5)$ & $\mathrm{Rh}(8)-\mathrm{P}(2)$ & $2.347(3)$ \\
$\mathrm{Rh}(1)-\mathrm{S}(2)$ & $2.3765(5)$ & $\mathrm{Rh}(8)-\mathrm{S}(7)$ & $2.392(3)$ \\
$\mathrm{Rh}(1)-\mathrm{B}(3)$ & $2.078(2)$ & $\mathrm{Rh}(8)-\mathrm{B}(9)$ & $2.159(10)$ \\
$\mathrm{Rh}(1)-\mathrm{B}(4)$ & $2.410(2)$ & $\mathrm{Rh}(8)-\mathrm{B}(3)$ & $2.238(12)$ \\
$\mathrm{Rh}(1)-\mathrm{B}(5)$ & $2.498(2)$ & $\mathrm{Rh}(8) \cdots \mathrm{B}(11)$ & $3.463(12)$ \\
$\mathrm{Rh}(1)-\mathrm{B}(6)$ & $2.380(2)$ & $\mathrm{Rh}(8) \cdots \mathrm{B}(10)$ & $3.333(11)$ \\
$\mathrm{Rh}(1)-\mathrm{B}(7)$ & $2.405(2)$ & $\mathrm{Rh}(8)-\mathrm{B}(4)$ & $2.249(10)$ \\
$\mathrm{B}(5)-\mathrm{B}(8)$ longest & $1.916(7)$ & $\mathrm{B}(2)-\mathrm{B}(3)$ longest & $1.883(17)$ \\
$\mathrm{B}(3)-\mathrm{B}(7)$ shortest & $1.712(6)$ & $\mathrm{B}(6)-\mathrm{B}(10)$ shortest & $1.748(16)$ \\
$\mathrm{P}(1)-\mathrm{Rh}(1)-\mathrm{P}(2)$ & $85.015(19)$ & $\mathrm{P}(1)-\mathrm{Rh}(8)-\mathrm{P}(2)$ & $82.96(9)$ \\
$\mathrm{S}(2)-\mathrm{Rh}(1)-\mathrm{B}(3)$ & $119.68(6)$ & $\mathrm{S}(7)-\mathrm{Rh}(8)-\mathrm{B}(9)$ & $93.3(3)$ \\
$\mathrm{N}(1)-\mathrm{B}(3)-\mathrm{Rh}(1)$ & $128.28(14)$ & $\mathrm{N}(1)-\mathrm{B}(9)-\mathrm{Rh}(8)$ & $122.3(7)$ \\
$\mathrm{S}(2)-\mathrm{Rh}(1)-\mathrm{P}(1)$ & $123.234(19)$ & $\mathrm{S}(7)-\mathrm{Rh}(8)-\mathrm{P}(1)$ & $168.85(9)$ \\
$\mathrm{S}(2)-\mathrm{Rh}(1)-\mathrm{P}(2)$ & $103.954(19)$ & $\mathrm{S}(7)-\mathrm{Rh}(8)-\mathrm{P}(2)$ & $94.30(9)$ \\
\hline
\end{tabular}


The dimensions of the dppe-ligated cluster, 2, are similar to those found for the bis$\mathrm{PMe}_{2} \mathrm{Ph}$-ligated counterpart, $\quad\left[1,1-\left(\mathrm{PMe}_{2} \mathrm{Ph}\right)_{2}-3-\left(\mathrm{NC}_{5} \mathrm{H}_{5}\right)\right.$-closo-1,2- $\left.\mathrm{RhSB}_{9} \mathrm{H}_{8}\right] .{ }^{5} \quad$ As expected, the Rh-P distances in the chelate are significantly shorter than in the derivative with monodentate phosphines. The structural effect of the chelating ligand also manifests in the smaller $\mathrm{P}(1)-\mathrm{Rh}(1)-\mathrm{P}(2)$ angle [85.015(19) vs. 96.27(4)].

The ellipsoids are shown at $50 \%$ probability levels. The hydrogen atom along the $B(9)-$ $\mathrm{B}(10)$ edge could not be found.

The molecular structure of the cationic cluster 3 was obtained from a weakly diffracting slightly twinned crystal sample. In addition, disorder was found involving triflate anions and solvent molecules. The twin nature of the crystal and the crystallographic disorder precluded a precise analysis, notwithstanding the data allowed the unambiguous characterization of the polyhedral cation in the crystal (see the Experimental section and $\mathrm{ESI}^{\ddagger}$ formore details).

The cluster exhibits an 11-vertex nido-cluster geometry with a five-membered $\left\{\mathrm{RhSB}_{3}\right\}$ open face (Fig. 1). This structural attribute is manifest by the $\operatorname{Rh}(8) \cdots B(10)$ and $\mathrm{Rh}(8) \cdots \mathrm{B}(11)$ non-bonding distances of $3.333(11)$ and 3.463(12) $\AA$, respectively, which in compound 2 correspond to the $\mathrm{Rh}(1)-\mathrm{B}(6)$ and $\mathrm{Rh}(1)-\mathrm{B}(5)$ bonding lengths of $2.380(2)$ and $2.498(2) \AA$. A common feature of this type of 11 -vertex nido-cages is that the $\{M(L) 2\}$ units are twisted away from a reference plane through $\{\mathrm{M}(8) \mathrm{B}(1) \mathrm{B}(6)\} .{ }^{4} \ln 3$, the dihedral angles $\theta$ between the plane formed by $\{P(1) R h(8) P(2)\}$ and the $\{S(7) R h(8) B(9)\}$ plane is $63^{\circ}$, resembling the angles found in other bis-L2-ligated nido-metallaheteroboranes. ${ }^{4}$

The angle between the $\{\mathrm{S}(7) \mathrm{Rh}(8) \mathrm{B}(9)\}$ and $\{\mathrm{S}(7) \mathrm{B}(2) \mathrm{B}(5) \mathrm{B}(9)\}$ planes, $\theta$, is appropriate to examine for intermediacy of structure between conventionally nido compounds and closo-cages. ${ }^{4}$ This angle is virtually zero in 11-vertex octadecahedral clusters such as compound 2 , and in compound 3 , the angle is $45^{\circ}$, close to the value of $48^{\circ}$, found in its isoelectronic neutral counterpart [8,8-( $\left.\eta^{2}-\mathrm{dppp}\right)-$ nido-8,7- $\left.\mathrm{RhSB}_{9} \mathrm{H}_{10}\right]$, which has been structurally well characterized by $\mathrm{X}$-ray diffraction analysis. ${ }^{16}$ 

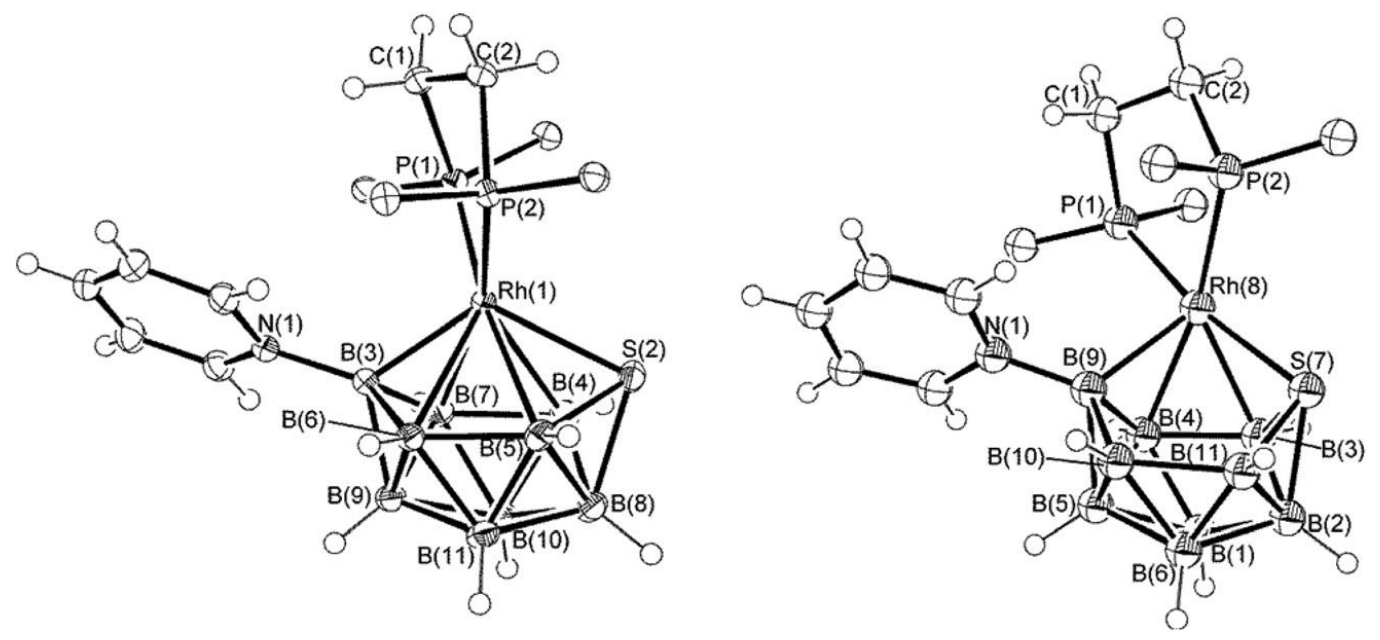

Fig. 1 ORTEP-type of drawing of [1,1-( $\left.\left.\eta^{2}-d p p e\right)-3-(\mathrm{NC5H} 5)-c l o s o-1,2-\mathrm{RhSB} 9 \mathrm{H} 8\right](2)$ and [8,8-( $\eta^{2}-$ dppe)-9-(NC5H5)-nido-8,7-RhSB9H9] ${ }^{+}(3)$.

It is interesting to note that according to Wade rules compounds $\mathbf{2}$ and $\mathbf{3}$ contain 12 skeletal electron pairs (sep), and both clusters are expected to exhibit an eleven-vertex closo-structure based on an octadodecahedral geometry. ${ }^{15}$ Therefore, the structure of compound $\mathbf{3}$ is an example of an 11-vertex cluster that adopts a more open structure. It has been noted before that a discrepancy between the electron-counting rules and the structure is common among polyhedral molecules that incorporate $C_{2 v}$ fragments such as $\mathrm{RhL}_{2}$ or $\mathrm{PtL}_{2} \cdot{ }^{17,18}$ In this regard, the rhodathiaborane $\left[8,8-\left(\mathrm{PPh}_{3}\right)_{2}\right.$-nido-8,7- $\mathrm{RhSB}_{9} \mathrm{H}_{10}$ ( precursor of $\mathbf{1}$, and hence of $\mathbf{2}$ and $\mathbf{3}$ ) has the same number of sep than $\mathbf{2}$ and $\mathbf{3}$ but its structure is that of an eleven-vertex cluster derived from an icosahedron by the removal of a vertex. ${ }^{19,20}$

The open nido-structures found in the neutral rhodathiaborane, [8,8- $\left(\mathrm{PPh}_{3}\right)_{2}$-nido-8,7$\mathrm{RhSB}_{9} \mathrm{H}_{10}$ ], and in the cationic pyridine adduct 3 arise by stabilization effects of the B$\mathrm{H}-\mathrm{B}$ bridging hydrogen atom on the pentagonal open face of both clusters (vide infra, Fig. $4)$, with concomitant preference of pseudo-square-planar $\{R h(L) 2\}$ centres for sixteenelectron configurations rather than eighteen-electron configurations.

The ${ }^{11} \mathrm{~B}-\left\{{ }^{1} \mathrm{H}\right\}$ NMR spectrum of the closo-rhodathiaborane, 2, shows six peaks in a $1: 1: 2: 1: 2: 2$ relative intensity ratio in the range $\delta\left({ }^{11} \mathrm{~B}\right)+53$ to -35 , which is in accord with a cluster of Cs-symmetry in solution. The pattern resembles readily the spectra of the previously reported, [1,1-( $\left.\mathrm{PR}_{3}\right)_{2}-3-\left(\mathrm{NC}_{5} \mathrm{H}_{5}\right)$-closo-1,2- $\left.\mathrm{RhSB}_{9} \mathrm{H}_{8}\right]$, where $\mathrm{PR}_{3}=\mathrm{PPh}_{3}$; $\mathrm{PMe}_{2} \mathrm{Ph} ; \mathrm{PMe}_{3} ; \mathrm{PPh}_{3}$ and $\mathrm{PMe}_{3}$; or $\mathrm{PPh}_{3}$ and $\mathrm{PMe}_{2} \mathrm{Ph}$ (Fig. 2). ${ }^{5}$ The highest frequency resonance corresponds to the pyridine-substituted $\mathrm{B}(3)$ vertex, being diagnostic of this 
type of polyhedral boron-based cluster. Fig. 2 illustrates the remarkable similarity of the ${ }^{11} \mathrm{~B}$ spectra among this series of eleven-vertex closo-rhodathiaboranes, suggesting that the change of the phosphine ligands at the rhodium centre does not alter significantly the overall shielding pattern of the boron nuclei. This trend could be viewed as a consequence of the cluster bonding network acting as an electron buffer capable of delocalizing any excess electron density at the metal centre. Thus, in principle, we could hypothesize that the alteration of the exo-polyhedral ligands at the rhodium centre does not have a large effect in the reactivity of the clusters, but this hypothesis is far to be true (vide infra). The ${ }^{31} \mathrm{P}-\{1 \mathrm{H}\}$ spectrum of 2 shows a doublet at $\delta\left({ }^{31} \mathrm{P}\right)$ +64.7 , which confirms the presence of the dppe ligand bound to the rhodium atom, and the $C_{\mathrm{s}}$-point symmetry of the cluster in solution.

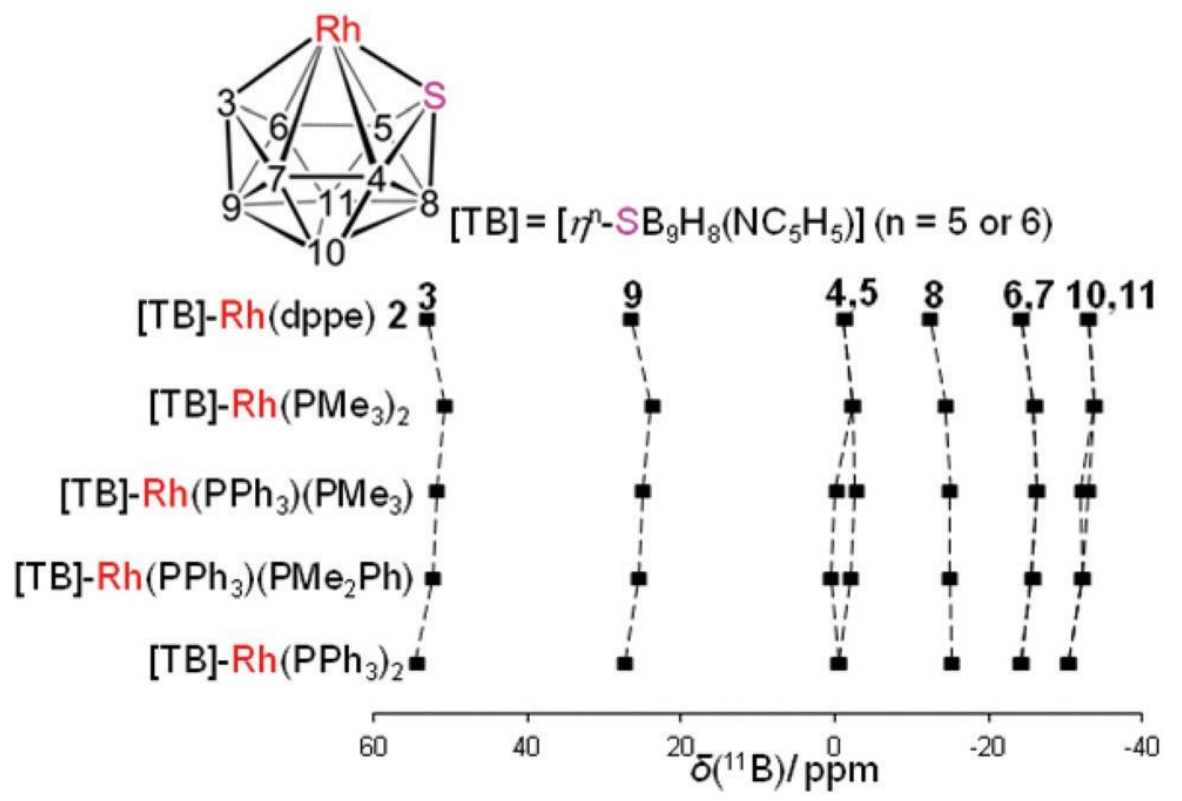

Fig. $2{ }^{11} \mathrm{~B}$ NMR spectra representation of 2 and of $\left\{\mathrm{Rh}\left(\mathrm{PR}_{3}\right)_{2}\right\}$ bis-ligated analogues, [1,1$\left(\mathrm{PR}_{3}\right)_{2}-3-(\mathrm{NC} 5 \mathrm{H} 5)-$-closo-1,2-RhSB ${ }_{9} \mathrm{H}_{8}$ ]. Hatched lines connect equivalent positions.

The ${ }^{11} \mathrm{~B}-\left\{{ }^{1} \mathrm{H}\right\}$ NMR spectrum of the cationic cluster 3 shows four peaks in the interval $\delta\left({ }^{11} \mathrm{~B}\right)+40$ to -23 with a $1: 1: 2: 5$ relative intensity ratio. This pattern implies a significant change with respect to the spectrum of the neutral reagent, 2 . Thus, upon protonation the resonance of the pyridine-substituted boron atom shifts $15 \mathrm{ppm}$ towards lower frequencies, whereas the other signals approach each other and overlay (see Fig. S1 ). It is important to note that in the case of the previously reported analogues, [1,1-( $\left.\mathrm{PR}_{3}\right)_{2}-3-\left(\mathrm{NC}_{5} \mathrm{H}_{5}\right)$-closo-1,2- $\left.\mathrm{RhSB}_{9} \mathrm{H}_{8}\right],{ }^{5}$ where $\mathrm{PR}_{3}=\mathrm{PMePh}_{2}, \mathrm{PPh}_{3}$ and $\mathrm{PMe}_{2} \mathrm{Ph}$; or $\mathrm{PMe}_{3}$ and $\mathrm{PPh}_{3}$, the ${ }^{11} \mathrm{~B}-\left\{{ }^{1} \mathrm{H}\right\}$ spectra of the protonated clusters exhibit 
the same pattern as the neutral parent clusters, suffering from only a small deshielding.

The ${ }^{11} \mathrm{~B}$ NMR data, therefore, suggest that compound 2 undergoes a significant structural and electronic change upon protonation to give 3 . This is confirmed by the analysis of the ${ }^{1} \mathrm{H}-\left\{{ }^{11} \mathrm{~B}\right\}$ spectrum that shows a broad singlet at $\delta\left({ }^{1} \mathrm{H}\right)-3.35$ that can be assigned to a $\mathrm{B}-\mathrm{H}-\mathrm{B}$ bridging hydrogen atom, being diagnostic of a closo-to-nido structural change (Scheme 1 and Fig. S2ł). Once again, this differs significantly from

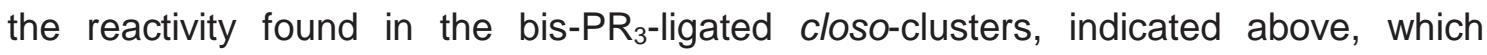
undergo selective protonation at the $R h(1)-B(3)$ edge, maintaining in solution the overall 11-vertex structure based on an octadecahedron.

An eleven-vertex nido-structure for $\mathbf{3}$ such as that depicted in Scheme 1 implies two ${ }^{31} \mathrm{P}$ nuclei with different chemical shifts, however, the $31 \mathrm{P}-\{1 \mathrm{H}\}$ NMR spectrum at room temperature exhibits a doublet at $\delta(31 \mathrm{P})+54.6$. This suggests that the cationic rhodathiaborane, $\mathbf{3}$, is stereochemically non-rigid undergoing intramolecular rearrangements that is equivalent the phosphorous-31 nuclei on the NMR time-scale.

We should point out the lower value of the ${ }^{1} \mathrm{JRhP}$ coupling constant in $3(118 \mathrm{~Hz})$ compared with that of $2(150 \mathrm{~Hz})$, suggests that protonation of the cage results in a marked different metal-to-thiaborane bonding interaction. A similar decrease in the ${ }^{1} \mathrm{JRhP}$ coupling constant was found upon protonation of [1,1-( $\left(\mathrm{PR}_{3}\right)_{2}-3-\left(\mathrm{NC}_{5} \mathrm{H}_{5}\right)$-closo1,2-RhSB ${ }_{9} \mathrm{H}_{8}$ ], where $\mathrm{PR}_{3}=\mathrm{PMePh}_{2}, \mathrm{PPh}_{3}$ and $\mathrm{PMe}_{2} \mathrm{Ph}$, or $\mathrm{PMe}^{3}$ and $\mathrm{PPh}_{3}$, to give the corresponding cationic species, [1,1-( $\left.\mathrm{PR}_{3}\right)_{2}-3-\left(\mathrm{NC}_{5} \mathrm{H}_{5}\right)$-closo-1,2-RhSBg $\left.\mathrm{H}_{9}\right]^{+} .^{11}$

\section{Variable temperature (VT) NMR studies}

NMR studies at low temperatures allow us to propose that compound $\mathbf{3}$ undergoes a rapid and reversible process of isomerisation in solution. Thus, the doublet in the ${ }^{31} \mathrm{P}-\left\{{ }^{1} \mathrm{H}\right\} \mathrm{NMR}$ spectrum at room temperature broadens and shifts towards higher frequencies as the temperature decreases. Then, the very broad resonance splits into three signals (Fig. 3). At $183 \mathrm{~K}$, the spectrum exhibits a broad doublet at $\delta\left({ }^{31} \mathrm{P}\right)+46.3$ and two overlaying doublets at $\delta\left({ }^{31} \mathrm{P}\right)+57.4$ and +58.0 .

This VT NMR behaviour is further illustrated in the corresponding ${ }^{1} \mathrm{H}-\left\{{ }^{11} \mathrm{~B}\right\}$ NMR spectra that reveal how the low frequency singlet at $-3.35 \mathrm{ppm}$ broadens significantly when the temperature decreases from 300 to $243 \mathrm{~K}$ (Fig. 3). Similar to the ${ }^{31} \mathrm{P}-\left\{{ }^{1} \mathrm{H}\right\}$ NMR spectrum, a more significant change occurs when the temperature is decreased further, and the $\mathrm{B}-$ $\mathrm{H}-\mathrm{B}$ bridging proton resonance shifts $4 \mathrm{ppm}$ towards lower frequencies at $183 \mathrm{~K}$. The 
resulting very broad proton resonance at $\delta\left({ }^{1} \mathrm{H}\right)-7.12$ is reminiscent of the low frequency multiplets found in the ${ }^{1} \mathrm{H}-\left\{{ }^{11} \mathrm{~B}\right\}$ spectra of the 11 -vertex cationic species $[1,1-(\mathrm{PR} 3) 2-1,3-\mu$ (H)-3-(NC5H5)-closo-1,2-RhSB9H8 $]^{+}$, where PR3 = PMePh2; $\mathrm{PPh} 3$ and $\mathrm{PMe} 2 \mathrm{Ph}$; or $\mathrm{PMe} 3$ and $\mathrm{PPh} 3$, which correspond to protons along the $\mathrm{Rh}(1)-\mathrm{B}(3)$ edges of these octadecahedral closo-clusters. ${ }^{11}$

Although in this case we do not observe either ${ }^{1} \mathrm{~J} R \mathrm{RH}$ or ${ }^{2} \mathrm{JPH}$ coupling constants ( probably due to the broadness of the peak), the low frequency proton resonance that results upon cooling 3 at $183 \mathrm{~K}$ can be assigned with good level of confidence to a bridging hydrogen atom along a Rh-B edge.
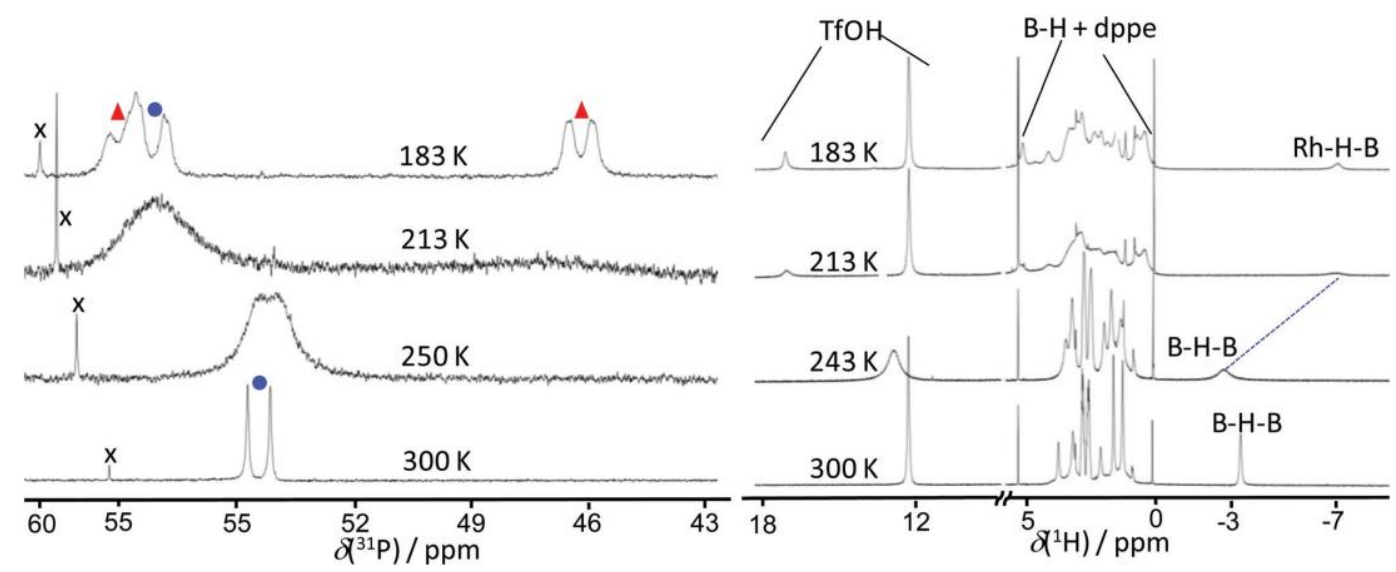

Fig. 3 Variable temperature (VT) ${ }^{31} \mathrm{P}-\left\{{ }^{1} \mathrm{H}\right\}$ (left) and ${ }^{1} \mathrm{H}-\left\{{ }^{11} \mathrm{~B}\right\}$ (right) NMR spectra of 3. The peaks marked with a red triangle in the $\mathrm{VT}^{31} \mathrm{P}-\left\{{ }^{1} \mathrm{H}\right\}$ correspond to the nidoisomer, and the overlapping peak marked with a blue circle is assigned to the closotautomer. The peak marked $x$ is due to an impurity.

Based on the VT NMR spectroscopic behaviour of 3, we propose that this cationic species undergoes rapid and reversible conversion of the nido rhodathiaborane cation to its closo-tautomer (Scheme 2). At higher temperatures, the major isomer is the nido-cluster featuring a pentagonal face on which the proton stays most probably along the $\mathrm{B}(9)-\mathrm{B}(10)$ edge. At lower temperatures, the equilibrium shifts towards the formation of the closotautomer in which the proton occupies most likely a position along the $\mathrm{Rh}(1)-\mathrm{B}(3)$ edge. The high mobility of this protic hydrogen atom and the consequent non-rigidity of the rhodathiaborane cluster do not allow the resolution of any coupling with either the rhodium or the phosphorous nuclei. 


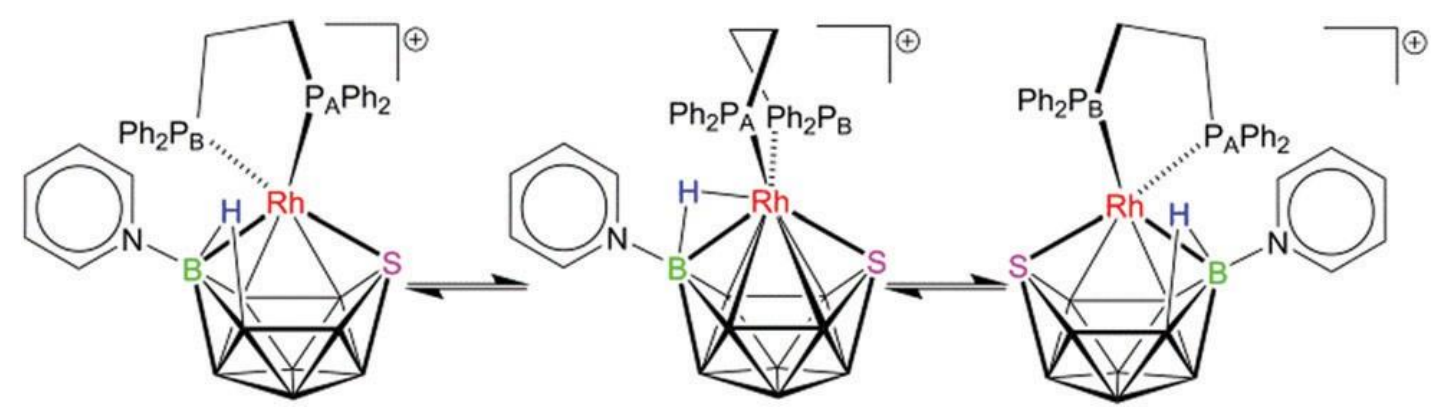

Scheme 2 Interconversion of nido- and closo-rhodathiaborane cations.

This prototropic nido-closo tautomerism can be described as the shift and half-rotation of the $\{R h(d p p e)\}$ vertex above the six-membered face $\{S(7) B(3) B(4) B(9) B(10) B(11)\}$ of the thiaborane moiety in the nido-cluster. As the metal centre moves from a tetrahapto ligation with the $\left\{\mathrm{SB} 9 \mathrm{H}_{8}\left(\mathrm{NC} 5 \mathrm{H}_{5}\right)\right\}$ fragment in the nido-isomer to an hexahapto ligation in the closotautomer, there is a reverse shift of the bridging hydrogen atom from the $B(9)-B(10)$ edge to the $R h(1)-B(3)$ edge. The exchange of the two phosphorous nuclei, demonstrated by NMR spectroscopy, implies the pseudo-rotation of the $\{\mathrm{Rh}(\mathrm{dppe})\}$ group that is performed via the closo-isomer. The two enantiomers of the nido-isomer interconvert in the course of this dynamic process (Scheme 2).

To facilitate the discussion below, it is convenient to bear in mind that the thiaborane fragment in these 11-vertex rhodathiaboranes forms donor-acceptor complexes or coordination compounds in which the $\{\mathrm{SB} 9 \mathrm{H} 9(\mathrm{C} 5 \mathrm{H} 5)\}$ moiety is acting as a ligand with different degrees of hapticity.

In previous studies, we had demonstrated that the cationic bis-PR3-ligated species, [(PMe3)(PPh3)(NC5H5)RhSB9H9] ${ }^{+}$, features a labile polyhapto ligation of the $\{\mathrm{SB} 9 \mathrm{H} 9(\mathrm{NC} 5 \mathrm{H} 5)\}$ moiety to the rhodium centre. This was determined in the solid state by the characterization of three different $\{\mathrm{Rh}(\mathrm{PPh} 3)(\mathrm{PMe} 3)\}$-to- $\left\{\eta^{n}\right.$ $\mathrm{SB9H} 8(\mathrm{NC} 5 \mathrm{H} 5)\}$ ( $n=4$ or 5$)$ conformers in the unit cell: an uncommon case of conformational isomerism.

The new dppe-ligated polyhedral cation, 3, features a more labile ligation of the thiaborane moiety to the $\{\mathrm{Rh}(\mathrm{dppe})\}$ vertex that results in a reversible nido $\leftrightarrow$ closo isomerisation. This dynamic behaviour implies rapid hapticity changes in the $\{\mathrm{Rh}(\mathrm{dppe})\}$-to- $\left\{\eta^{n}\right.$-SB9H8(NC5H5)\} linkage from $\eta^{6}$ in the closo isomer to $\eta^{4}$ in the nido- 
cluster, which is the structure determined in the solid state by X-ray crystallography (Fig. 1).

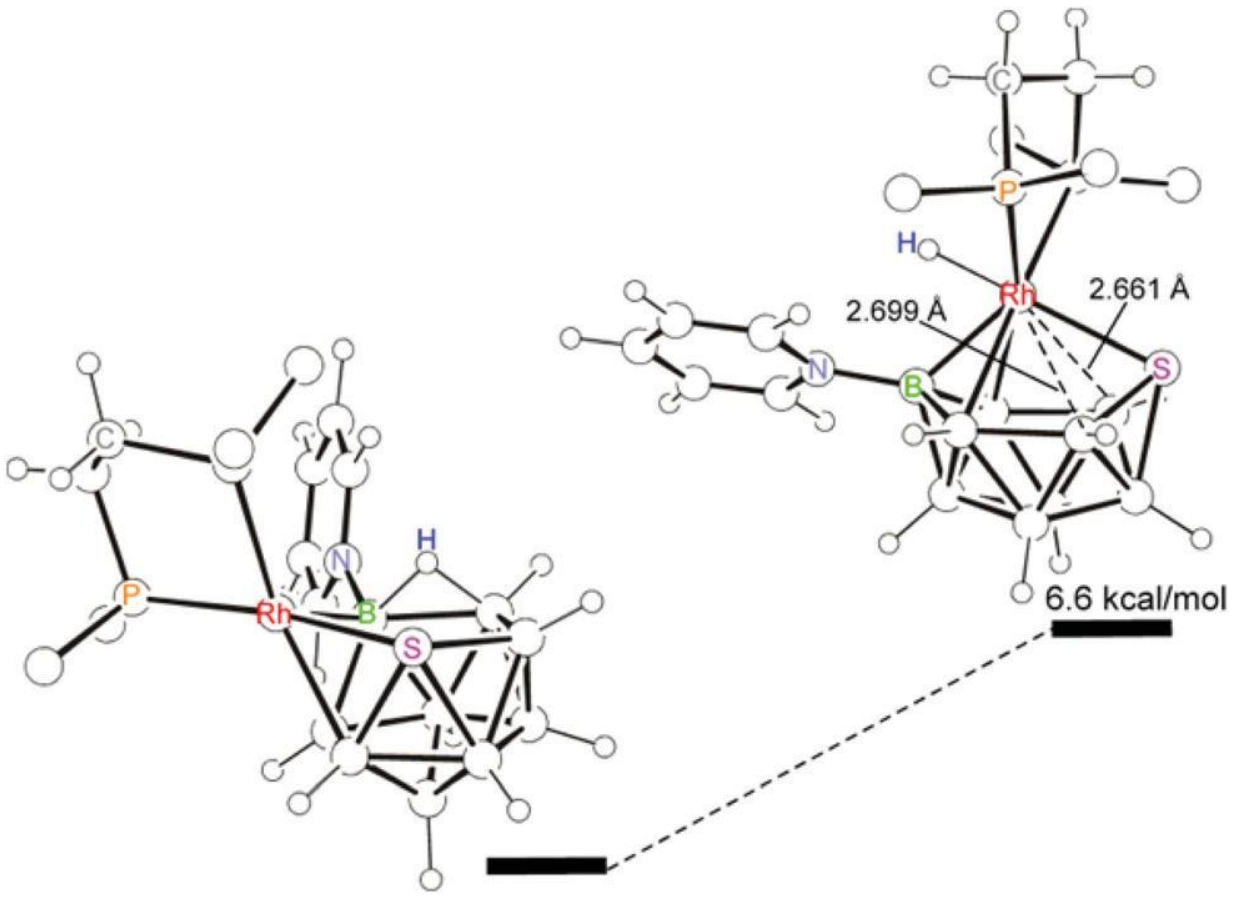

Fig. 4 DFT-calculated energies and structures, computed at the B3LYP/6-31G*/LANL2DZ level for the nido- and closo-isomers of $\mathbf{3}$.

The stereochemical non-rigidity of compound $\mathbf{3}$, demonstrated by VT NMR spectroscopy, implies a low energy difference between the nido- and closo-isomers and a low free energy barrier for the isomerisation process. DFT-calculations show that the optimized nido-structure of 3 is $6.6 \mathrm{kcal} \mathrm{mol}^{-1}$ lower in energy than that of the closoisomer (Fig. 4). Although small, this difference is larger than the $2.5 \mathrm{kcal} \mathrm{mol}^{-1}$ calculated for the cationic nido and closo isomers [(PMe3)(PPh3)$\left.(\mathrm{NC} 5 \mathrm{H} 5) \mathrm{RhSB} 9 \mathrm{H}_{9}\right]^{+} .{ }^{11}$ This result is in agreement with the NMR spectroscopic data which revealed that the closo-isomer is the only species detected in solution for this bis-PR3ligated 11-vertex polyhedral cation.

Regarding the free energy value of the nido/closo tautomerization, for simplicity, the dynamic process has been treated as an equally populated two-site exchange involving the two doublets marked with red triangles in Fig. 3. This treatment has provided a free energy, $\Delta G^{\ddagger}$, of $8.6 \mathrm{kcal} \mathrm{mol}^{-1}$ (see ESI $\ddagger$ for more details).

This rapid interconversion between tautomers is clearly reminiscent of the fluxional behavior that exhibits eleven-vertex nido-metallaheteroboranes based on the nido- 
[MEB9H10] unit, where $\mathrm{M}=\mathrm{Rh}, \mathrm{E}=\mathrm{NH}$ or $\mathrm{S}$; and $\mathrm{M}=\mathrm{Pt}, \mathrm{E}=\mathrm{CH} .{ }^{18,19,21}$ Thus, the fluxional behaviour of these species is similarly owed to a rapid internal "switching" and half-rotation of the metal centre across the formal $\{\mathrm{EB} 9 \mathrm{H} 10\}$ 'mirror plane'. The transition state for this fluxional process, calculated for [8,8- (PH3)2-nido-8,7-RhEB9H10], where $\mathrm{E}$ is $\mathrm{NH}$ or $\mathrm{S},{ }^{18}$ features a $\mathrm{Rh}(1)-\mathrm{H}-\mathrm{B}(3)$ bridging bond in a $C_{S}$ closo-type eleven-vertex geometry that resembles the structure proposed for the closo- isomer of compound 3.

Table 2 Free energy values for the rearrangement processes involved in eleven-vertex metallaheteroboranes

\begin{tabular}{|c|c|c|}
\hline Compound & $\Delta \mathrm{G}^{\ddagger}\left(\mathrm{kcal} \mathrm{mol}^{-1}\right)$ & Ref. \\
\hline [(PPh3)2RhSB9H10] & 14 & 19 \\
\hline [(PPh2Me)2RhSBgH10] & 12 & 6 \\
\hline [(dppp)RhSB9H10] & 13 & 22 \\
\hline [(dppp)RhSBgH9(OEt)] & $>15$ & 22 \\
\hline [(dppe)RhSBgH10] & $11^{a}$ & This work \\
\hline$\left[(\mathrm{dppe}) \mathrm{RhSB} 9 \mathrm{H} 9\left(\mathrm{NC}_{5} \mathrm{H}_{5}\right)\right]^{+}(\mathbf{3})$ & 9 & This work \\
\hline [(PPh3)2RhNB9H11] & 11 & 18 \\
\hline [(PMe2Ph)2PtCB9H11] & 15 & 21 \\
\hline [(PMe2Ph)2PtCB9H10(OEt)] & $>18$ & 18 \\
\hline
\end{tabular}

$a$ This cluster was reported in ref. 16 and 22 but its fluxional behavior is reported here for the first time.

Table 2 lists the free energy values for the rearrangement processes involved in neutral eleven-vertex metallaheteroboranes of general formulation, [8,8-(L)2-nido-8,7MEB9H10], where $\mathrm{M}=\mathrm{Rh}, \mathrm{E}=\mathrm{NH}$ or $\mathrm{S} ; \mathrm{M}=\mathrm{Pt}, \mathrm{E}=\mathrm{CH}$; and $(\mathrm{L}) 2=$ mono- dentate or bidentate phosphine ligands, together with the energy measured in this work for the cationic species 3 . The data reveal that 3 exhibits a lower energy barrier than the neutral species, demonstrating that the ligation of the thiaborane moiety to the metal centre is more labile. 


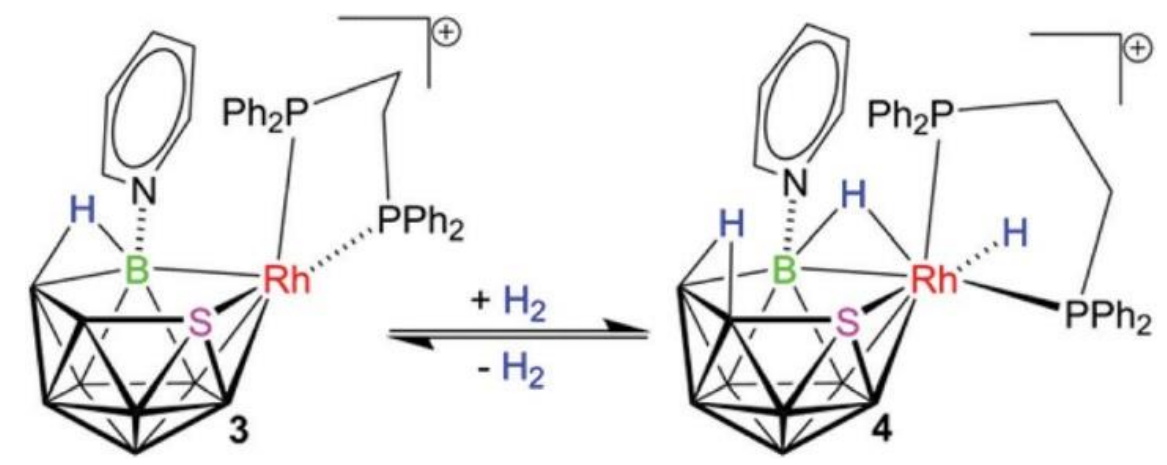

Scheme 3 Reversible reaction of $\mathbf{3}$ with H2. For clarity, only one isomer for $\mathbf{4}$ is depicted (vide infra).

\section{Reactivity with dihydrogen}

The activation of dihydrogen by polyhedral boron containing-compounds is rare. Thus, there are few examples of metallaheteroboranes that react with $\mathrm{H} 2$ to give the additional products as the result of the heterolytic splitting of the $\mathrm{H}-\mathrm{H}$ bond on the clusters. ${ }^{8,12,13,23}$ The red, air stable rhodium complex, 2, does not react under an atmosphere of 10 bar of dihydrogen. In contrast, the orange-red cationic species, $\mathbf{3}$, reacts instantaneously with $\mathrm{H} 2$ to give a pale yellow solution. The study of this reaction system by multielement NMR spectroscopy has allowed the characterization of two new cationic hydridorhodathiaboranes.

The ${ }^{1} \mathrm{H}-\left\{{ }^{11} \mathrm{~B}\right\}$ NMR spectrum of the reaction mixture shows a pseudo-quintet and pseudo-quartet at $\delta\left({ }^{1} \mathrm{H}\right)-10.83$ and -11.32 in a $0.7: 1$ relative intensity ratio, respectively. These two resonances can be safely assigned to $\mathrm{Rh}-\mathrm{H}$ hydride ligands of two complexes. Between -5 and $-7 \mathrm{ppm}$, the ${ }^{1} \mathrm{H}-\left\{{ }^{11} \mathrm{~B}\right\}$ NMR spectrum displays a pseudo-triplet and a doublet of doublets also in a $0.7: 1$ intensity ratio. These signals broaden significantly, losing the coupling constants, when the broad band boron decoupler is turned off. Therefore, these resonances can be assigned to hydrogen atoms that occupy bridging positions along the $\mathrm{Rh}(8)-\mathrm{B}(9)$ edge of two eleven-vertex nido-clusters. Inthenegative region of the spectrum there are also two broad peaks at -3.39 and $-4.06 \mathrm{ppm}$ with a 1:0.7 relative intensity ratio, respectively. These resonances broaden in the ${ }^{1} \mathrm{H}$ NMR spectrum, being diagnostic of the presence of $\mathrm{B}-\mathrm{H}-\mathrm{B}$ bridging hydrogen atoms in the deltahedral clusters (the ${ }^{1} \mathrm{H},{ }^{11} \mathrm{~B}$, and ${ }^{31} \mathrm{P}$ spectra are depicted in Fig. S1, ESI ).

The ${ }^{31} \mathrm{P}-\left\{{ }^{1} \mathrm{H}\right\}$ NMR spectrum of this reaction mixture is also quite informative. At $223 \mathrm{~K}$, there are four doublets of doublets between $\delta\left({ }^{31} \mathrm{P}\right)+75$ and +60 in a 1:1:0.7:0.7 relative intensity ratio. These ${ }^{31} \mathrm{P}$ resonances correspond to the chelating phosphine ligands of two 
clusters that contain the $\{\mathrm{RhH}(\mathrm{dppe})\}$ fragment as structural constituent. $\left[{ }^{1} \mathrm{H}-{ }^{31} \mathrm{P}\right]-\mathrm{HMBC}$ experiments allowed the correlation of the proton resonances of the hydrides ligands with the dppe ligands to which they are associated at the rhodium centre. The assignment agrees with the correlation that is inferred from the analysis of the relative intensities found in the ${ }^{1} \mathrm{H}$ and ${ }^{31} \mathrm{P} \mathrm{NMR}$ spectra.

According to these NMR data, we propose that the reaction between $\mathbf{3}$ and $\mathrm{H} 2$ affords a mixture of two hydridorhodathiaborane isomers of formulation, $\left[8,8,8-(\mathrm{H})\left(\eta^{2}-\mathrm{dppe}\right)-\mu-8,9-(\mathrm{H})-\right.$ 9- (NC5H5)-nido-8,7-RhSB9H9] ${ }^{+}$(4) (Scheme 3).

Interestingly, the ${ }^{31} \mathrm{P}-\left\{{ }^{1} \mathrm{H}\right\}$ NMR spectrum of the isomeric mixture, 4 , under a 10 bar atmosphere of $\mathrm{H} 2$ at $300 \mathrm{~K}$ (Fig. S4 $\ddagger$ ) shows a doublet at $+54.6 \mathrm{ppm}$ that corresponds to the cationic parent complex, 3. In addition, the release of dihydrogen in the quick valve pressure NMR tube results in a significant increase of $\mathbf{3}$. These observations allow us to conclude that the mixture of hydridorhodathiaboranes, $\mathbf{4}$, and the reactant, $\mathbf{3}$, are in equilibrium. To our knowledge, this cationic system together with the previously reported carbene-ligated pair, [1,1-(IMe)(PPh3)-3-(NC5H5)-closo-1,2-RhSB9H8] and [8,8,8$(\mathrm{H})(\mathrm{IMe})(\mathrm{PPh} 3)-9-(\mathrm{NC} 5 \mathrm{H} 5)$-nido-8,7-RhSB9H9], where $\mathrm{IMe}=$ 1,3-di-methylimidazol-2-ylidene, represent the only cases of chemical equilibria between polyhedral boron-based clusters sustained by the reversible splitting of $\mathrm{H} 2$.

DFT-calculations revealed that the tautomers with the hydrogen atoms along the $\mathrm{B}(10)$ $B(11)$ and $R h(8)-B(9)$ edges afforded stable local energy minima, whereas the structures with bridging hydrogen atoms along the $\mathrm{B}(9)-\mathrm{B}(10)$ or $\mathrm{S}(7)-\mathrm{B}(11)$ were not stable. Thus, the two isomers, characterized by multielement NMR spectroscopy, are attributed to the different tetrahapto ligation of the thiaborane moiety to rhodium. There are three limiting configurations that can describe the $\{\mathrm{Rh}(\mathrm{H})(\mathrm{dppe})\}$-to- $\left\{\eta^{4}-\mathrm{SB} 9 \mathrm{H}_{10}\left(\mathrm{NC}_{5} \mathrm{H} 5\right)\right\}$ linkage, which were optimized by DFT-calculations and are depicted in Fig. 5. 


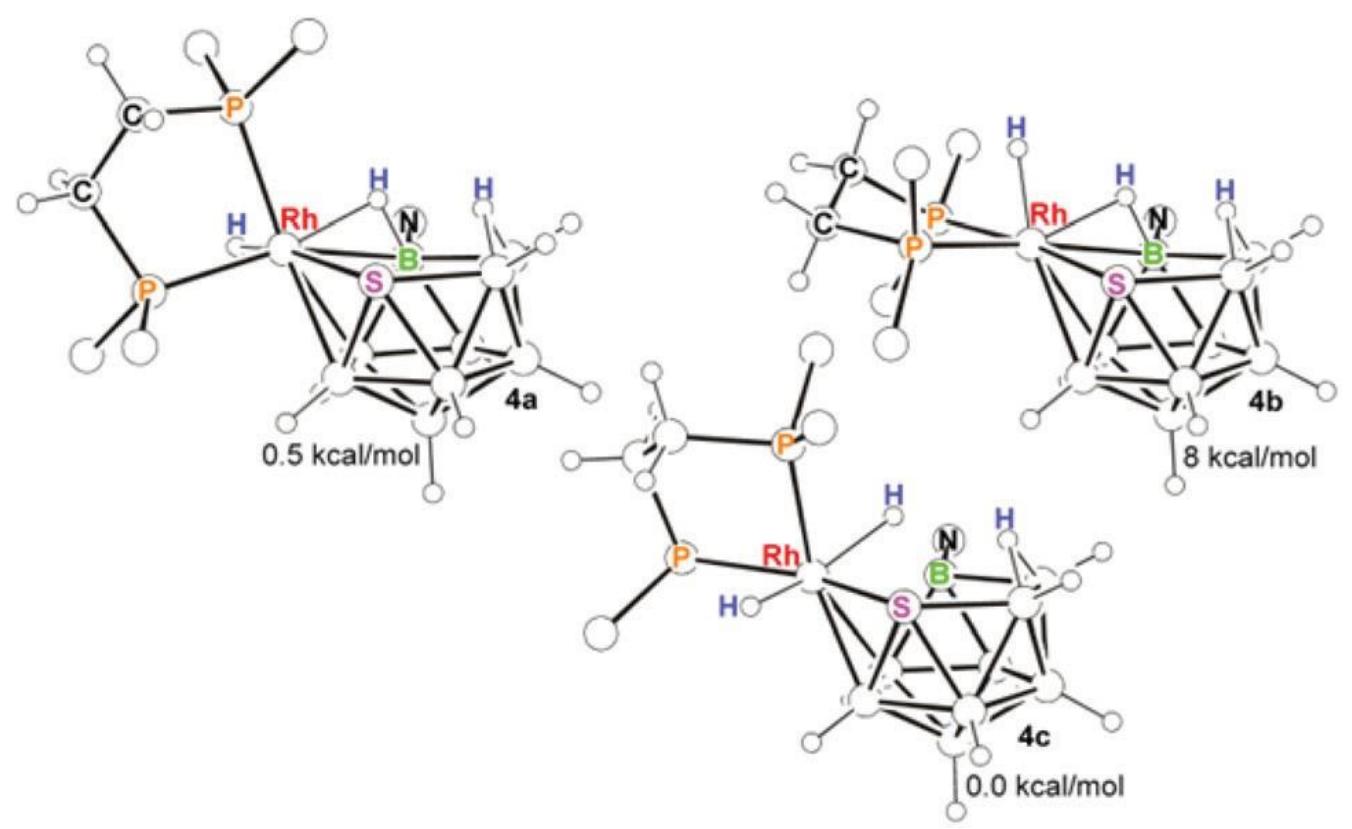

Fig. 5 Energy comparisons for DFT optimized metal-to-thiaborane configurational isomers of 4.

The three calculated isomers exhibit low energy differences, being the highest energy isomer compared with the hydride ligand trans to the $\mathrm{B}(3)-\mathrm{B}(4)$ edge, $\mathbf{4 b}$. In a similar fashion to the metallacarboranes, we have found that the exo-polyhedral configuration at the metal centre in hydridorhodathiaboranes is directed by the sulphur atom, which drives the hydride ligand trans to the position of this heteroatom. Based on these observations, we expected to find in $\mathbf{4}$ this ligand orientation as the most stable $\{\mathrm{Rh}(\mathrm{H})(\mathrm{dppe})\}$-to- $\left\{\eta^{n}\right.$ $\left.\mathrm{SB} 9 \mathrm{H}_{10}\left(\mathrm{NC}_{5} \mathrm{H}_{5}\right)\right\}$ configuration. It was surprising, therefore, to find that the optimization of the isomer with the hydride ligand trans to the $\mathrm{B}(9)$ vertex afforded a cluster, $\mathbf{4 c}$, with an energy that lies $0.5 \mathrm{kcal} \mathrm{mol}^{-1}$ lower than the isomer, $4 \mathbf{a}$, with the hydride trans to the sulphur vertex (Fig. 5). However, this cluster exhibits a long $\mathrm{Rh}(8)-B(9)$ distance at 2.773 $\AA$ (versus $2.478 \AA$ and $2.410 \AA$ in the isomers $4 \mathbf{a}$ and 4 b, Fig. 5) that is clearly non-bonding. The resulting DFT-calculated isomer $4 \mathrm{c}$ features a trihapto ligation of the $\{\mathrm{SB} 9 \mathrm{H} 9(\mathrm{NC} 5 \mathrm{H} 5)\}$ moiety to a $\{\mathrm{Rh}(\mathrm{H}) 2(\mathrm{dppe})\}$ group with two hydride ligands trans to each other. This DFTcalculated configuration is expected to result in a very large ${ }^{2} \mathrm{JHH}$ coupling constant involving the hydrides, which is not observed experimentally. In conclusion, given the small energy differences between the three calculated structures, it is reasonable to assign the clusters $\mathbf{4 a}$ and $\mathbf{4 b}$ in Fig. 5 as the isomers detected by NMR. A clockwise 
$\{\mathrm{Rh}(\mathrm{H})(\mathrm{dppe})\}-$ to- $\eta^{4}-\{\mathrm{SB} 9 \mathrm{H} 9(\mathrm{NC} 5 \mathrm{H} 5)\}$ rotation of $\sim 90^{\circ}$ in 4 a results in the formation of $\mathbf{4 b}$. In the isomer $\mathbf{4 b}$, the facial disposition of the $\mathrm{Rh}(8)-\mathrm{H}$ hydride ligand, and the $\mathrm{Rh}(8)-\mathrm{H}-\mathrm{B}(9)$ and $\mathrm{B}(10)-\mathrm{H}-\mathrm{B}(11)$ hydrogen atoms may facilitate the reversible release of $\mathrm{H}_{2}$, perhaps, through the formation of a $\mathrm{Rh}-\left(\mathrm{n}^{2}-\mathrm{H}_{2}\right)$ dihydrogen intermedite that would be comparable to the side-on bonded dihydrogen complex, $\left[8,8,8-\left(\eta^{2}-\mathrm{H} 2\right)(\mathrm{IMe})(\mathrm{PPh} 3)-9-\right.$ (NC5H5)-nido-8,7-RhSB9H8], calculated by DFT. ${ }^{12}$

\section{Experimental section}

\section{General considerations}

All reactions were carried out under an argon atmosphere using standard Schlenkline techniques. Solvents were obtained from Innovative Technology's solvent purification system. [8,8,8-(H)(PPh3)2-9-(NC5H5)-nido-8,7-RhSB9H9] (1), was prepared according to the literature method. ${ }^{8,9}$ Commercially available 1,2bis(diphenylphosphino)ethane (dppe) was used as received without further purification. Preparative thin-layer chromatography (TLC) was carried out using $1 \mathrm{~mm}$ layers of silica gel G (Fluka, type GF254) made from water slurries on glass plates of dimensions $20 \times$ $20 \mathrm{~cm}$ and dried in air at $25^{\circ} \mathrm{C}$. Infrared spectra were recorded on a Perkin-Elmer Spectrum 100 spectrometer, using a universal ATR sampling accessory. NMR spectra were recorded on Bruker Avance $300 \mathrm{MHz}$ and AV $400 \mathrm{MHz}$ spectrometers, using ${ }^{11} \mathrm{~B},{ }^{11} \mathrm{~B}-\left\{{ }^{1} \mathrm{H}\right\},{ }^{1} \mathrm{H}$, ${ }^{1} \mathrm{H}-\left\{{ }^{11} \mathrm{~B}\right\},{ }^{1} \mathrm{H}-\left\{{ }^{11} \mathrm{~B}\right.$ (selective) $\}$ and ${ }^{31} \mathrm{P}-\left\{{ }^{1} \mathrm{H}\right\}$ techniques. ${ }^{1} \mathrm{H}$ chemical shifts were measured relative to partially deuterated solvent peaks but are reported in ppm relative to tetramethylsilane. ${ }^{11} \mathrm{~B}$ chemical shifts were measured relative to $\left.[\mathrm{BF} 3(\mathrm{OEt}) 2)\right] .{ }^{31} \mathrm{P}$ (121.48 MHz) chemical shifts were measured relative to $\mathrm{H} 3 \mathrm{PO} 4$ (85\%). Mass spectrometric data were recorded on a MICROFLEX instrument operating in either positive or negative mode, using matrix-assisted laser desorption/ionization (MALDI). A nitrogen laser of $337 \mathrm{~nm}$ (photon energy of $3.68 \mathrm{eV}$ ) was used for the ionization processes, and the molecules nder study were protected with a matrix of trans-2-[3-(4-tert-butylphenyl)-2-methyl2-propenylidene]malononitrile (DCTB). In each case there was an excellent correspondence between the calculated and measured isotopomer envelopes. A well-matched isotope pattern may be taken as a good criterion of identity.

\section{$X$-ray structural analysis for compounds 2 and 3}


Crystals were grown by slow diffusion of hexane into a dichloromethane solution of the corresponding rhodathiaboranes, 2 and 3. A suitable crystal of each cluster was coated with perfluoropolyether, mounted on a glass fiber and fixed in a cold nitrogen stream ( $T=100(2)$ K) to the goniometry head. In the case of $\mathbf{3}$, several crystals were scrutinized to optimize size (intensity) and the twin nature; eventually a not very intense but slightly twinned crystal was selected as the best compromise for data collection. Data collection were performed on a Bruker Kappa APEX DUO CCD area detector diffractometer with monochromatic radiation $\lambda(\mathrm{MoK \alpha})=0.7107073 \AA$, using narrow frames $\left(0.3^{\circ}\right.$ in $\left.\omega\right)$. Intensities were integrated including Lorentz and polarization effects with the SAINT-Plus program ${ }^{24}$ and corrected for absorption effects by multiscan methods (SADABS). ${ }^{25}$ The structures were solved using the -SHELXS-97 program, and refined against all $F$ data by full matrix least-squares techniques $($ SHELXL-97). 27 Both structures were refined first with isotropic and later with anisotropic displacement parameters for non-disordered non-H atoms. Specific relevant details on each structure are described below. CCDC 1043935 and 1044383 contain the supplementary crystallographic data for this paper.

Crystal data for 2. $\mathrm{C} 31 \mathrm{H} 37 \mathrm{~B} 9 \mathrm{NP} 2 \mathrm{RhS} \cdot 2\left(\mathrm{CH}_{2} \mathrm{Cl} 2\right) ; M=887.67$; red prism $0.238 \times 0.157 \times$ $0.102 \mathrm{~mm}^{3}$; triclinic; $\overline{P 1} ; a=9.8610(10), b=10.3668(10), c=19.485(2) \AA$, $\alpha=93.404(2)^{\circ}, \beta=$ $91.461(2)^{\circ}, Y=100.0580(10)^{\circ} ; Z=2 ; V=1956.5(3) \AA^{3} ; D c=1.507 \mathrm{~g} \mathrm{~cm}^{-3} ; \mu=0.873 \mathrm{~mm}^{-1}$; $\min$. and max. absorption correction factors 0.809 and $0.898 ; 2 \theta \max =59.16^{\circ} ; 34075$ reflections collected, 10118 unique ( $R$ int $=0.033)$; number of data/restraints/parameters 10 118/0/608; final GOF 1.044; $R 1=0.0303$ (8620 reflections, $I>2 \sigma(I)$ ); $w R\left(F^{2}\right)=0.0731$ for all data. Hydrogen atoms were observed in Fourier difference maps and freely refined, except $\mathrm{H} 60 \mathrm{~A}$ and $\mathrm{H60B}$, in the dichloromethane molecule which were included from observed positions and refined with displacement riding parameters.

Crystal data for 3. $\mathrm{C}_{31} \mathrm{H}_{38} 8 \mathrm{BNP}_{2} \mathrm{RhS}^{+} \mathrm{CF}_{3} \mathrm{O}_{3} \mathrm{~S}^{-} \cdot \mathrm{CHF}_{3} \mathrm{O}_{3} \mathrm{SCH}_{2} \mathrm{Cl}_{2} ; M=1102.90$; orange block $0.271 \times 0.164 \times 0.074 \mathrm{~mm}^{3}$; monoclinic; $C 2 / c ; a=11.2683(15), b=20.906(3), c=$ 39.689(5) $\AA, \beta=91.817(2)^{\circ} ; Z=8 ; V=9345(2) \AA^{3} ; D_{\mathrm{C}}=1.568 \mathrm{~g} \mathrm{~cm}^{-3} ; \mu=0.750 \mathrm{~mm}^{-1}$; $\min$. and max. absorption correction factors 0.744 and $0.916 ; 2 \theta \max =52.74^{\circ} ; 42710$ reflections collected, 9525 unique $(R$ int $=0.1109)$; number of data/restraints/parameters 9525/24/587; final GOF 1.272; $R 1=0.1114$ (7443 reflections, $I>2 \sigma(I)$; $w R\left(F^{2}\right)=0.2554$ for all data. All organic terminal hydrogens were included in calculated positions and refined 
with a usual riding strategy; the bridging hydrogen of the metallaborane, and those of the triflic acid and of the solvent molecule were not included in the model. Static disorder was observed both for a $\mathrm{CF}_{3} \mathrm{SO} 3$ moiety - refined with some geometrical restrictions and for a solvent highly disordered dichloromethane molecule.

\section{Calculations}

Calculations were performed using the Gaussian 09 package. ${ }^{28}$ Structures were initially optimized using standard methods with the STO-3G* basis-sets for C, B, P, S, and H with the LANL2DZ basis-set for the metal atom. The final optimizations, including frequency analyses to confirm the true minima were performed using B3LYP methodology, with the 6-31G* and LANL2DZ basis-sets.

\section{[1,1-( $\eta^{2}$-dppe)-3-(NC5H5)-closo-1,2-RhSB9H8] (2)}

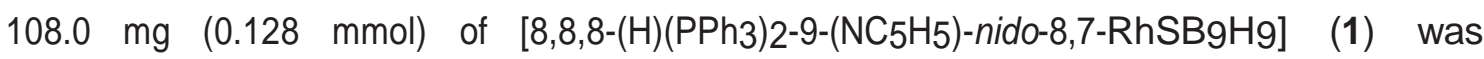
dissolved in $10 \mathrm{~mL}$ of $\mathrm{CH}_{2} \mathrm{Cl}_{2}$ in a Schlenk tube under an atmosphere of argon. Next, $50.8 \mathrm{mg}(0.128 \mathrm{mmol})$ of dppe was added, and the reaction mixture was stirred at $55^{\circ} \mathrm{C}$ for 16 h. The resulting orange solution was concentrated under vacuum, and applied to preparative TLC plates. Elution with $9: 1 \mathrm{CH}_{2} \mathrm{Cl} 2 /$ hexane gave an orange band $(R f=0.32)$, from which an orange product was isolated, after washing the silica-gel with pure dichloromethane. The product was characterized as 2; after crystallization from $\mathrm{CH}_{2} \mathrm{Cl} 2 /$ hexane, we isolated $48 \mathrm{mg}\left(55 \%\right.$ yield). ${ }^{11} \mathrm{~B}-\left\{{ }^{1} \mathrm{H}\right\}(128 \mathrm{MHz})$ and ${ }^{1} \mathrm{H}-\left\{{ }^{11} \mathrm{~B}\right\} \mathrm{NMR}$ $(300 \mathrm{MHz})$ in $\mathrm{CD} 2 \mathrm{Cl} 2$ at $300 \mathrm{~K})$ \{cluster resonances ordered as: assignment $\delta\left({ }^{11} \mathrm{~B}\right) / \mathrm{ppm}$ $\left[\delta\left({ }^{1} \mathrm{H}\right) / \mathrm{ppm}\right.$ for directly attached exo-hydrogen]\}: $\mathrm{B}(3)+53.2(B-\mathrm{NC} 5 \mathrm{H} 5), \mathrm{BH}(9)+26.6[+3.98]$, $2 \mathrm{BH}(4,5)-1.1$ [+2.09], $\mathrm{BH}(8)-12.5$ [+2.59], 2BH $(6,7)-24.2[-0.14], 2 \mathrm{BH}(10,11)-32.9[-0.21]$. Additional ${ }^{1} \mathrm{H}$ NMR data are: $\delta=+7.89\left(\mathrm{~m}, 4 \mathrm{H} ; \mathrm{Ho}_{\mathrm{O}} \mathrm{NC} 5 \mathrm{H} 5+\mathrm{C} 6 \mathrm{H} 5\right),+7.73(\mathrm{~m}, 4 \mathrm{H} ; \mathrm{C} 6 \mathrm{H} 5)$, $+7.37\left(\mathrm{~m}, 7 \mathrm{H} ; \mathrm{H}_{\mathrm{O}}-\mathrm{NC} 5 \mathrm{H} 5+\mathrm{C} 6 \mathrm{H} 5\right),+7.28\left(\mathrm{t},{ }^{3} \mathrm{JHH}=8.0 \mathrm{~Hz}, 4 \mathrm{H} ; \mathrm{C}_{6} \mathrm{H}_{5}\right),+7.14\left(\mathrm{t},{ }^{3} \mathrm{JHH}=\right.$ $\left.8.0 \mathrm{~Hz}, 2 \mathrm{H} ; \mathrm{Hm}_{-} \mathrm{NC} 5 \mathrm{H} 5\right),+7.08\left(\mathrm{~m}, 4 \mathrm{H} ; \mathrm{C} 6 \mathrm{H}_{5}\right),+2.45\left(\mathrm{~m}, 2 \mathrm{H} ; \mathrm{CH}_{2}\right),+2.05(\mathrm{~m}, 2 \mathrm{H}$; $\mathrm{CH} 2) .{ }^{31} \mathrm{P}-\left\{{ }^{1} \mathrm{H}\right\} \mathrm{NMR}\left(162 \mathrm{MHz}, \mathrm{CD}_{2} \mathrm{Cl} 2,298 \mathrm{~K}\right): \delta=+64.7\left(\mathrm{~d},{ }^{1} \mathrm{JRhP}=150 \mathrm{~Hz}\right)$. Anal. Calcd for C31H37B9NP2RhS: C, 51.87; H, 5.19; N, 1.95; S, 4.45. Found: C, 50.75; H, 5.03; $\mathrm{N}, 2.06$; S 4.63. LRMS (MALDI'/DCTB): m/z: calcd for C31H35B9NP2RhS: 716.7 [M $(3 \mathrm{H})]^{+}$; found 716.2. Isotope envelopes match those calculated from the known isotopic abundances of the constituent elements. 


\section{[8,8-(n²-dppe)-9-(NC5H5)-nido-8,7-RhSB9H9][OTf] (3)}

$32.3 \mathrm{mg}(0.045 \mathrm{mmol})$ of [1,1-( $\eta^{2}$-dppe)-3-( $\left.\mathrm{NC} 5 \mathrm{H} 5\right)-$ - closo-1,2-RhSB9H8] (2) was dissolved in $5 \mathrm{~mL}$ of $\mathrm{CH}_{2} \mathrm{Cl}_{2}$ in a Schlenk tube under an atmosphere of argon. The resulting orange suspension was treated with $6.76 \mathrm{mg}(0.045 \mathrm{mmol})$ of triflic acid $(\mathrm{TfOH})$, and the reaction mixture was stirred at room temperature for 30 minutes. The solvent was reduced under vacuum until an approximate volume of $0.5 \mathrm{~mL}$. Addition of hexane gave an orange precipitate that was washed with hexane $(3 \times 3 \mathrm{~mL})$. The solid was dried under vacuum, and it was characterized as compound 3 . The compound was crystallized from $\mathrm{CH}_{2} \mathrm{Cl}_{2} /$ hexane to give $38 \mathrm{mg}\left(96 \%\right.$ yield). ${ }^{11} \mathrm{~B}-\left\{{ }^{1} \mathrm{H}\right\}(128 \mathrm{MHz})$ and ${ }^{1} \mathrm{H}-\left\{{ }^{11} \mathrm{~B}\right\} \mathrm{NMR}(300 \mathrm{MHz})$ in $\mathrm{CD} 2 \mathrm{Cl} 2$ at $300 \mathrm{~K})$ \{cluster resonances ordered as: assignment $\delta\left({ }^{11} \mathrm{~B}\right) / \mathrm{ppm}\left[\delta\left({ }^{1} \mathrm{H}\right) / \mathrm{ppm}\right.$ for directly attached exo-hydrogen]\}: $\mathrm{B}(9)+38.2(\mathrm{~B}-\mathrm{NC} 5 \mathrm{H} 5), \mathrm{BH}+15.1$ [+3.75], $2 \mathrm{BH}+11.6[+3.19]$, $5 \mathrm{BH}-17.2[1 \mathrm{H}+2.10,2 \mathrm{H}+1.61,2 \mathrm{H}+1.26]$. Additional ${ }^{1} \mathrm{H}-\left\{{ }^{11} \mathrm{~B}\right\} \mathrm{NMR}$ data are: $\delta=+8.25$ $\left(\mathrm{t},{ }^{3} \mathrm{JHH}=8.0 \mathrm{~Hz}, 1 \mathrm{H} ; \mathrm{Hp}-\mathrm{NC} 5 \mathrm{H} 5\right),+7.61$ to +7.39 (m, 24H; Ho-NC5H5, Hm-NC5H5, C6H5), $+2.95(\mathrm{~m}, 2 \mathrm{H} ; \mathrm{CH} 2),-3.35\left(\mathrm{~s}, 1 \mathrm{H}\right.$; BHB). ${ }^{31} \mathrm{P}-\left\{{ }^{1} \mathrm{H}\right\} \mathrm{NMR}\left(162 \mathrm{MHz}, \mathrm{CD}_{2} \mathrm{Cl} 2,300 \mathrm{~K}\right): \delta=$ $+54.6\left(\mathrm{~d},{ }^{1} \mathrm{JRhP}=118 \mathrm{~Hz}\right) .{ }^{31} \mathrm{P}-\left\{{ }^{1} \mathrm{H}\right\} \mathrm{NMR}(162 \mathrm{MHz}, \mathrm{CD} 2 \mathrm{Cl} 2,183 \mathrm{~K}): \delta=c a .+58.0$ (this resonance overlays with the next doublet), +57.4 (br. d, ${ }^{1} \mathrm{JRhP}=141 \mathrm{~Hz}$ ), +46.3 (br. d, ${ }^{1} \mathrm{JRhP}$ $=123 \mathrm{~Hz}$ ). Anal. Calcd for C32H38B9F3NO3P2RhS2: C, 44.28; H, 4.41; N, 1.61; S, 7.39. Found: $\mathrm{C}, 42.81 ; \mathrm{H}, 4.32 ; \mathrm{N}, 1.69$; S 7.52. LRMS (MALDI $\left.{ }^{-} / \mathrm{DCTB}\right): \mathrm{m} / \mathrm{z}$ : calcd for C31H34B9NP2RhS: $715.7[\mathrm{M}-(4 \mathrm{H})]^{+}$; found 715.2. Isotope envelopes match those calculated from the known isotopic abundances of the constituent elements.

Reaction of [8,8-( $\eta^{2}$-dppe)-9-(NC5H5)-nido-8,7-RhSB9H9][OTf] (3) with $\mathrm{H} 2$. In a quick pressure valve NMR tube, $3 \mathrm{mg}(0.015 \mathrm{mmol})$ of 3 was dissolved in $0.3 \mathrm{~mL}$ of $\mathrm{CD}_{2} \mathrm{Cl}_{2}$. The tube was evacuated under vacuum at liquid nitrogen temperature, and subsequently, exposed to 10 bar of hydrogen. The resulting sample was studied by NMR spectroscopy. The data were consistent with the presence in a $1: 0.7$ ratio of two cationic hydridorhodathiaboranes of formulation, [8,8,8-( $\left.\eta^{2}-\mathrm{dppe}\right)(\mathrm{H})-9-(\mathrm{NC} 5 \mathrm{H} 5)-$-nido-8,7$\mathrm{RhSB9H} 10]^{+}$. The isomers were not separated and the NMR data below correspond to samples that contain both species. NMR ${ }^{11} \mathrm{~B}-\left\{{ }^{1} \mathrm{H}\right\}(128 \mathrm{MHz} ; \mathrm{CD} 2 \mathrm{Cl} 2 ; 298 \mathrm{~K}): \delta=+16.6$, $+11.1,+4.8,+3.7,-8.8,-12.1,-13.1,-15.9,-17.1,-19.8,-23.4,-24.8$. The signals are broad 
and indistinguishable for both isomers. NMR ${ }^{1} \mathrm{H}-\left\{^{11} \mathrm{~B}\right\}(400 \mathrm{MHz}, \mathrm{CD} 2 \mathrm{Cl} 2,290 \mathrm{~K}): \delta=$ $+8.60\left(\mathrm{~d},{ }^{3} \mathrm{HHH}=6.0 \mathrm{~Hz}, 2 \mathrm{H} ; \mathrm{H}_{0}-\mathrm{NC} 5 \mathrm{H} 5\right),+8.21\left(\mathrm{t},{ }^{3} \mathrm{JHH}=7.6 \mathrm{~Hz}, 1 \mathrm{H} ; \mathrm{Hp}_{-}-\mathrm{NC} 5 \mathrm{H} 5\right)$, $+8.00\left(\mathrm{t},{ }^{3} \mathrm{JHH}=8.0 \mathrm{~Hz}, 1 \mathrm{H} ; \mathrm{Hp}_{-} \mathrm{NC} 5 \mathrm{H} 5\right),+7.92$ to $+6.81\left(\mathrm{~m}, 40 \mathrm{H} ; \mathrm{C}_{6} \mathrm{H}_{5}+\mathrm{NC} 5 \mathrm{H} 5\right)$, $+4.01(\mathrm{~s}, 1 \mathrm{H} ; \mathrm{BH}),+3.80(\mathrm{~s}, 0.7 \mathrm{H} ; \mathrm{BH}),+3.58(\mathrm{~s}, 1 \mathrm{H} ; \mathrm{BH}),+3.27(\mathrm{~m}, 1 \mathrm{H} ; \mathrm{CH} 2),+2.98$ (m, 2H; CH2), +2.89 (s, 1H; BH), +2.79 (m, 2H, CH2), +2.61 (m, 2H, CH2), +2.41 (s, 3H; $\mathrm{BH}),+2.35\left(\mathrm{~m}, 0.7 \mathrm{H} ; \mathrm{CH}_{2}\right),+1.83(\mathrm{~s}, 1 \mathrm{H} ; \mathrm{BH}),+1.75(\mathrm{~s}, 0.7 \mathrm{~B} ; \mathrm{BH}),+1.67$ (s, 1B; BH), +1.35 (s, 1B; BH), -3.39 (s, 1H; BHB), -4.06 (s, 0.7H; BHB), -5.79 (pseudo t, 0.65H, $\left.{ }^{1} \mathrm{JRhH}+{ }^{2} \mathrm{JPH}=15 \mathrm{~Hz}, \mathrm{BHRh}\right),-6.72\left(\mathrm{dd},{ }^{1} \mathrm{JRhH}=55 \mathrm{~Hz},{ }^{2} \mathrm{JPH}=16 \mathrm{~Hz}, 1 \mathrm{H} ; \mathrm{BHRh}\right)$, -10.83 (pseudo quintet, ${ }^{1} \mathrm{JHRh}+{ }^{2} \mathrm{JHP}+{ }^{2} \mathrm{JHH}=14.0 \mathrm{~Hz}, 0.7 \mathrm{H}$; RhH), -11.32 (pseudo quartet, $\left.{ }^{1} \mathrm{JHRh}+{ }^{2} \mathrm{JHP} \approx 23 \mathrm{~Hz} ; 1 \mathrm{H} ; \mathrm{RhH}\right) . \mathrm{NMR}^{31} \mathrm{P}-\left\{{ }^{1} \mathrm{H}\right\}(162 \mathrm{MHz} ; \mathrm{CD} 2 \mathrm{Cl} 2 ; 223 \mathrm{~K}): \delta$ $=+72.9\left(\mathrm{br} . \mathrm{dd},{ }^{1} \mathrm{JRhP}=117 \mathrm{~Hz},{ }^{2} \mathrm{JPP}=19 \mathrm{~Hz}, 1 \mathrm{PA}\right.$; isomer A), $+67.4\left(\mathrm{dd},{ }^{1} \mathrm{JRhP}=93\right.$ $\mathrm{Hz},{ }^{2} \mathrm{JPP}=17 \mathrm{~Hz}, 1 \mathrm{PA}$; isomer A), $+65.4\left(\mathrm{dd},{ }^{1} \mathrm{JRhP}=133 \mathrm{~Hz},{ }^{2} \mathrm{JPP}=9 \mathrm{~Hz}, 0.7 \mathrm{~PB}\right.$; isomer $\mathrm{B}),+61.3\left(\mathrm{brdd},{ }^{1} \mathrm{JRhP}=97 \mathrm{~Hz},{ }^{2} \mathrm{JPP}=9 \mathrm{~Hz}, 0.7 \mathrm{~PB}\right.$; isomer $\left.\mathrm{B}\right) .\left[{ }^{1} \mathrm{H}-{ }^{31} \mathrm{P}\right]-\mathrm{HMBC}$ $(400 \mathrm{MHz}, \mathrm{CD} 2 \mathrm{Cl} 2,193 \mathrm{~K})$ \{ordered as $(\delta \mathrm{H}, \delta \mathrm{P})$ correlation\}: $(-11.32,+73.6),(+3.09$, +73.6), (+2.55, +73.6), (-11.32, +67.9), (+2.34, +67.9), (-10.83, +65.7), (+3.39, +61.8), (+2.94, $+61.8),(+2.15,+61.8)$; all the ${ }^{31} \mathrm{P}$ resonances exhibit correlations with aromatic signals.

\section{Conclusions}

The hydridorhodathiaborane, $\mathbf{1}$, reacts with the bidentate phosphine, dppe, to give the chelate, $\mathbf{2}$, as product of PPh3 substitution at the metal centre and cluster dehydrogenation. This simple synthetic procedure can be a priori extended to other bidentate phosphine ligands, being a potentially convenient way of tuning the reactivity of these 11-vertex rhodathiaboranes by the modification of the composition of the ligands at the metal centre. It has been already demonstrated that the change of the metal-bound ligands in pyridine-ligated 11-vertex rhodathiaboranes [1,1-(PR3)2-3-(NC5H5)-closo-1,2-RhSB9H8] has large consequences in their reactivity with strong Brønsted acids. ${ }^{11,13,14}$ In this regard, the bisPPh3-ligated closo-derivative reacts with $\mathrm{TfOH}$ to afford an equilibrium that involves the cationic species [1,1-(PPh3)2- $\mu-1,3-(\mathrm{H})-3-(\mathrm{NC} 5 \mathrm{H} 5)-$-closo-1,2-RhSB9H8 $]^{+}$, and neutral OTfligated compound [8,8-(TfO)(PPh3)-3-(NC5H5)-nido-8,7-RhSB9H9] and [HPPh3 $]^{+}$, which is formed upon protonation of the released PPh3 ligand. ${ }^{13}$ The introduction of more basic 
phosphines such as $\mathrm{PMe} 3$ and $\mathrm{PMe} 2 \mathrm{Ph}$ hinders the dissociation of the ligands upon protonation of the cage, stabilizing the cationic clusters, [1,1-(PPh3)2- $\mu-1,3-(\mathrm{H})-3-(\mathrm{NC} 5 \mathrm{H} 5)-$-closo1,2-RhSB9H8 $]^{+}$. Interestingly, a crystal of the bis-PPh3PMe3-ligated cation was found to contain three different isomers in the unit cell, one featuring an 11-vertex nido-structure. ${ }^{11}$ This uncommon case of conformational isomerism implies a labilization of the ligation between the pyridine-substituted thiaborane moiety and the rhodium center, which is promoted by protonation. In solution, however, these cationic clusters do not exhibit dynamic processes that could involve stereochemical non-rigid molecules.

The new work reported herein demonstrates that the chelating phosphine, dppe, induces a higher level of non-rigidity, leading to the formation of prototropic closo $\leftrightarrow$ nido equilibrium in solution. This tautomerization involves a proton shift between bridging positions along the $\mathrm{Rh}(1)-\mathrm{B}(3)$ and the $\mathrm{B}(9)-\mathrm{B}(10)$ edges of the closo-and nido-tautomers, respectively.

This interconversion between tautomers is performed through hapticity changes in the ligation between the pyridine-substituted thiaborane moiety and the rhodium centre. This dynamic process together with the enhancement of the Lewis acidity that occurs upon protonation of the cluster facilitates the interaction of the dihydrogen molecule with the cationic rhodathiaborane, 2, leading to the efficient heterolytic splitting of the $\mathrm{H}-\mathrm{H}$ bond and the subsequent formation of the hydridorhodathiaboranes, $4 a$ and $\mathbf{4 b}$. A further illustration of the different reactivity induced by the phosphine ligands is the fact that the mixture of isomers, $\mathbf{4 a}$ and $\mathbf{4 b}$, is unstable in the absence of an atmosphere of $\mathrm{H}_{2}$, regenerating the parent cation, 2, by release of dihydrogen. This contrasts with the bis- PR3-ligated analogues, [8,8,8-(H)(PR3)2-9-(NC5H5)-nido-8,7-RhSB9H10 $]^{+}$, where PR3 = PPh3, PPh3 and PMe3, or, $\mathrm{PPh} 3$ and $\mathrm{PMe} 2 \mathrm{Ph}$, which are stable in the absence of free $\mathrm{H}_{2} .8,29$

Insisting in the introductory paragraph, the possibility to modify the chemical and structural basis of this class of 11- vertex rhodathiaboranes is without doubt a driving force behind the study of the reaction chemistry of these polyhedral clusters. In this regard, the protonation of metallaheteroboranes to enhance their stereochemical non-rigidity and their Lewis acidity is a simple method that, in principle, could be of general application in polyhedral boron-containing compounds. The results reported herein and in previous studies augur well for tailoring new metallaheteroboranes that may be useful in, for example, solving problems in catalysis. 


\section{Notes and references}

1 Applied Homogeneous Catalysis with Organometallic Compounds, ed. B.

Cornils and W. A. Herrmann, Wiley-VCH Verlag GmbH, 2008.

2 J. D. Kennedy, in Prog. Inorg. Chem, John Wiley \& Sons, Inc., 2007, pp. 519-

679; J. D. Kennedy, in Prog. Inorg. Chem, John Wiley \& Sons, Inc., 2007, pp. 211-434;

L. Barton and D. K. Strivastava, in Comprehensive Organometallic Chemistryll, ed. E.

W. Abel, F. G. A. Stone and G. Wilkinson, Pergamon, New York, 1995, vol. 1, pp. 275372; A. S. Weller, in Comprehensive Organometallic Chemistry III, ed. R. H. Crabtree and D. M. P. Mingos, Elsevier, Oxford, 2007, vol. 3, pp. 133-174; R. N. Grimes, in Comprehensive Organometallic Chemistry, ed. G. Wilkinson, F. G. A. Stone and E. W. Abel, Pergamon Press Ltd, Oxford, 1982, ch. 5.5, vol. 1, pp. 459-542; R. N. Grimes, in Comprehensive Organometallic Chemistry II, ed. E. W. Abel, F. G. A. Stone and G. Wilkinson, Pergamon, Oxford, 1995, vol. 1, pp. 373-430; L. Wesemann, in Comprehensive Organometallic Chemistry, ed. D. M. P. Mingos and R. H. Crabtree, Elsevier, Oxford, 2007, vol. 3, pp. 113-131; N. S. Hosmane and J. A. Maguire, in Comprehensive Organometallic Chemistry III, ed. D. M. P. M. H. Crabtree, Elsevier, Oxford, 2007, pp. 175-264.

3 A. Alvarez, R. Macias, M. J. Fabra, M. L. Martin, F. J. Lahoz and L. A. Oro, Inorg. Chem., 2007, 46, 6811-6826.

4 B. Calvo, R. Macías, M. J. Artigas, F. J. Lahoz and L. A. Oro, Inorg. Chem., 2012, 52, 211-221.

5 B. Calvo, Á. Álvarez, R. Macías, P. García-Orduña, F. J. Lahoz and L. A. Oro, Organometallics, 2012, 31, 2986-2995.

6 B. Calvo, M. Kess, R. Macias, C. Cunchillos, F. J. Lahoz, J. D. Kennedy and L. A. Oro, Dalton Trans., 2011, 40, 6555-6564.

7 Á. Álvarez, R. Macías, J. Bould, C. Cunchillos, F. J. Lahoz and L. A. Oro, Chem. - Eur. J., 2009, 15, 5428-5431.

8 Á. Álvarez, R. Macías, M. J. Fabra, F. J. Lahoz and L. A. Oro, J. Am. Chem. Soc., 2008, 130, 2148-2149.

9 Á. Álvarez, R. Macías, J. Bould, M. J. Fabra, F. J. Lahoz and L. A. Oro, J. Am. Chem. Soc., 2008, 130, 11455-11466.

10 B. Calvo, B. Roy, R. Macías, M. J. Artigas, F. J. Lahoz and L. A. Oro, Inorg. Chem., 2014, 000; B. Calvo, M. Keß, R. Macias, R. Sancho, F. J. Lahoz and L. A. Oro, 
J. Coord. Chem., 2014, 1-12.

11 B. Calvo, R. Macias, M. J. Artigas, F. J. Lahoz and L. A. Oro, Dalton Trans., 2014, 43, 5121-5133.

12 B. Calvo, R. Macias, V. Polo, M. J. Artigas, F. J. Lahoz and L. A. Oro, Chem. Commun., 2013, 49, 9863-9865.

13 B. Calvo, R. Macías, M. J. Artigas, F. J. Lahoz and L. A. Oro, Chem. - Eur. J., 2013, 19, 3905-3912.

14 B. Calvo, R. Macías, C. Cunchillos, F. J. Lahoz and L. A. Oro, Organometallics, 2012, 31, 2526-2529.

15 K. Wade, Adv. Inorg. Chem. Radiochem., 1976, 18, 1-66.

16 K. J. Adams, T. D. McGrath, G. M. Rosair, A. S. Weller and A. J. Welch, J. Organomet. Chem., 1998, 550, 315-329.

17 D. G. Evans and D. M. P. Mingos, J. Organomet. Chem., 1982, 240, 321-327;

J. D. Kennedy, Main Group Met. Chem., 1989, 12, 149-154; J. D. Kennedy, in The Borane-Carborane-Carbocation Continuum, ed. J. Casanova, Wiley, New York, 1998, pp. 85-116; J. Bould, S. J. Teat and J. D. Kennedy, Collect. Czech. Chem. Commun., 2007, 72, 1631-1638; J. Bould, P. A. Cooke, U. Dorfler, J. D. Kennedy, L. Barton, N. P. Rath and M. Thornton-Pett, Inorg. Chim. Acta, 1999, 285, 290-295.

18 R. Macías, J. Bould, J. Holub, J. D. Kennedy, B. Štibr and M. Thornton-Pett, Dalton Trans., 2007, 2885-2897.

19 G. Ferguson, M. C. Jennings, A. J. Lough, S. Coughlan, T. R. Spalding, J. D. Kennedy, X. L. R. Fontaine and B. Stibr, J. Chem. Soc., Chem. Commun., 1990, 891894.

20 J. Bould and R. Macías, J. Organomet. Chem., 2014, 761, 120-122.

21 B. Stibr, T. Jelinek, J. D. Kennedy, X. L. R. Fontaine and M. Thornton-Pett, J. Chem. Soc., Dalton Trans., 1993, 1261-1267.

22 R. Macías, N. P. Rath and L. Barton, Organometallics, 1999, 18, 3637-3648.

23 Z. J. Yao, X. K. Huo and G. X. Jin, Chem. Commun., 2012, 48, 6714-6716.

24 Bruker, SAINT-PLUS (Version 6.01), M. Bruker AXS Inc., WI, 2001.

25 G. M. Sheldrick, SADABS Program for Correction of Area Detector Data, University of Göttingen, Göttingen, Germany, 1999.

26 G. Sheldrick, Acta Crystallogr., Sect. A: Fundam. Crystallogr., 1990, 46, 467- 
473.

27 G. M. Sheldrick, Acta Crystallogr., Sect. A: Fundam. Crystallogr., 2008, 64, 112-122.

28 M. J. Frisch, G. W. Trucks, H. B. Schlegel, G. E. Scuseria, M. A. Robb, J. R. Cheeseman, J. A. Montgomery, Jr., T. Vreven, K. N. Kudin, J. C. Burant, J. M. Millam, S. S. lyengar, J. Tomasi, V. Barone, B. Mennucci, M. Cossi, G. Scalmani, N. Rega, G. A. Petersson, H. Nakatsuji, M. Hada, M. Ehara, K. Toyota, R. Fukuda, J. Hasegawa, M. Ishida, T. Nakajima, Y. Honda, O. Kitao, H. Nakai, M. Klene, X. Li, J. E. Knox, H. P. Hratchian, J. B. Cross, V. Bakken, C. Adamo, J. Jaramillo, R. Gomperts, R. E. Stratmann, O. Yazyev, A. J. Austin, R. Cammi, C. Pomelli, J. Ochterski, P. Y. Ayala, K. Morokuma, G. A. Voth, P. Salvador, J. J. Dannenberg, V. G. Zakrzewski, S. Dapprich, A. D. Daniels, M. C. Strain, O. Farkas, D. K. Malick, A. D. Rabuck, K. Raghavachari, J. B. Foresman, J. V. Ortiz, Q. Cui, A. G. Baboul, S. Clifford, J. Cioslowski, B. B. Stefanov, G. Liu, A. Liashenko, P. Piskorz, I. Komaromi, R. L. Martin, D. J. Fox, T. Keith, M. A. Al-Laham, C. Y. Peng, A. Nanayakkara, M. Challacombe, P. M. W. Gill, B. G. Johnson, W. Chen, M. W. Wong, C. Gonzalez and J. A. Pople, Gaussian, Inc., Wallingford, CT, 2004.

29 Á. Álvarez, B. Calvo, R. Macías, F. J. Lahoz and L. A. Oro, Organometallics, 2014, 33, 3137-3153. 